\title{
Mapeamento da paisagem sonora: impactos dos sons da fé
}

\author{
Mapping the soundscape: impacts of the sounds of faith
}

\author{
Poliana Lopes de Oliveira [a] [D, Maria Lúcia Gondim da Rosa Oiticica [b] [D], \\ Erasmo Felipe Vergara Miranda [c] [D
}

[a] Universidade Federal de Santa Catarina (UFSC), Programa de Pós-Graduação em Arquitetura e Urbanismo,

Florianópolis, SC, Brasil

[b] Universidade Federal de Alagoas (UFAL), Departamento de Arquitetura e Urbanismo, Maceió, AL, Brasil

[c] Universidade Federal de Santa Catarina (UFSC), Departamento de Engenharia Mecânica/Programa de Pós-

Graduação em Arquitetura e Urbanismo, Florianópolis, SC, Brasil

Como citar: Oliveira, P. L., Oiticica, M. L. G. R., \& Miranda, E. F. V. (2021). Mapeamento da paisagem sonora: impactos dos sons da fé. urbe. Revista Brasileira de Gestão Urbana, v.13, e20210073. https://doi.org/10.1590/2175-

3369.013.e20210073

\section{Resumo}

O campo religioso brasileiro vem passando por transformações, como a diversificação de religiões e, com isso, o aumento de locais de celebrações. Os sons religiosos podem extrapolar os limites físicos da edificação e passar a compor a paisagem sonora local. Diante disto, este trabalho tem como objetivo investigar os impactos sonoros provocados por templos no loteamento Village Campestre, Maceió, Alagoas, Brasil, que possui em média setenta templos, principal motivo para justificá-la como área do estudo. A metodologia adotada constituiu uma análise dos sons por meio de mapeamentos, sendo eles mapas sonoros de NPS e mapas sonoros perceptivos, os dados base foram obtidos, respectivamente, através de medições in situ (com e sem funcionamento dos templos) e questionário. Os resultados mostraram um modelo de mapeamento para identificação e análise de fontes sonoras pontuais. Os sons dos templos impactam na paisagem sonora local, pois os níveis de pressão sonora ultrapassam em média $20 \mathrm{~dB}(\mathrm{~A})$ dos valores determinados pela NBR 10151:2019. No entanto, os dados qualitativos apontaram que a percepção dos sons religiosos como agradável foi quatro vezes maior do que como desagradável. Sendo assim, o modelo de análise resultou em informações relevantes sobre a paisagem sonora local por considerar mapas qualitativos e quantitativos.

Palavras-chave: Mapeamento sonoro. Paisagem sonora. Templos.

\section{Abstract}

The Brazilian religious field has been undergoing transformations, such as the diversification of religions and, in consequence, the increase in places for celebration. Religious sounds can overcome the physical limits of the building and become part of the local soundscape. In this respect, this work aims to investigate the sound impacts

PLO é arquiteta e urbanista, doutoranda em Arquitetura e Urbanismo, e-mail: polianalopes.ufal@gmail.com

MLGRO é arquiteta e urbanista, doutora em Engenharia Civil, e-mail: mloiticica@hotmail.com

EFVM é engenheiro acústico, doutor em Engenharia Mecânica, e-mail: e.f.vergara@ufsc.br 
caused by religious places of worship in the Village Campestre district of Maceió, Alagoas, Brazil, which has an average of seventy such places and is the main reason for justifying it as the focus for investigation in this study. The methodology adopted comprised an analysis by means of sound maps (noise and perceptive maps) that were obtained from in situ measurements and questionnaire. The results showed a mapping model for point source identification and analysis. The sounds of the worship impact the local soundscape because the sound pressure levels exceed, on average, $20 \mathrm{~dB}(A)$ of the values determined by NBR 10151:2019. However, the qualitative data showed that the sound perception of faith was classified four times more pleasant than unpleasant. The sounds of the worship impact the local soundscape because the sound pressure levels exceed $20 \mathrm{~dB}(A)$ of the values recommended by the ABNT NBR 10151:2019. Therefore, the analysis model resulted in relevant information on the local soundscape by considering qualitative and quantitative maps.

Keywords: Sound mapping. Soundscape. Places of worship.

\section{Introdução}

A configuração no campo religioso brasileiro vem passando por alterações, sendo uma delas a diminuição do número de católicos e o aumento do de evangélicos. Essa mudança foi intensificada na década de 1980, com o fim da garantia estatal, aumentando as possibilidades para a pluralização religiosa. Com a diversificação de religiões, houve também maior número de locais de celebrações próximos a residências (Brandão \& Jorge, 2019). O espraiamento de templos no espaço urbano implicou disputa de território, onde a apropriação do espaço perpassa a delimitação física e atinge questões perceptivas como o ambiente sonoro (Kovačič, 2018).

As ondas sonoras transgridem facilmente as fronteiras espaciais e mediam entre o público e privado. As práticas sônicas desempenham um papel fundamental na sacralização dos espaços religiosos. Os modos de adoração, pregação e oração, o uso de uma tecnologia de som e a arquitetura "aberta" de suas edificações combinam-se para estabelecer um espaço sagrado auditivo que não está contido nos limites físicos e, assim, invade o espaço público (De Witte, 2008).

Alguns estudos sobre os sons religiosos e suas relações com a cidade adotam a abordagem de paisagem sonora, por ser uma linha de investigação que permite a conexão entre indivíduo, contexto, som, tempo e espaço (Henriques, 2017; Kovačič, 2018; Kovačič, 2017; Robert \& Hayden, 2013; Oliveira, 2017).

Henriques (2017) estudou os sons de instituições religiosas de Angra, capital religiosa do arquipélago dos açores, no século XVII, sob a abordagem da paisagem sonora como patrimônio cultural. Kovačič (2018) analisou as relações entre o toque do sino e os moradores locais em Ljubljana, capital da Eslovênia, e investigou o pertencimento deste som à paisagem sonora local. Robert \& Hayden (2013) estudaram o ambiente sonoro de locais religiosos no mundo que são compartilhados ou contestados por diferentes comunidades religiosas. Esses estudos possuem em comum o debate a respeito da relatividade no grau de aceitação dos sons religiosos, que estão vinculados, dentre outros fatores, ao contexto em que estes estão inseridos.

As pesquisas sobre paisagem sonora abordam o ambiente sonoro além dos aspectos epidemiológicos e instigam os debates a respeito da dicotomia entre o tratamento institucional do som na cidade, com dados quantitativos predominantes, e a experiência da percepção sonora pelos habitantes, que envolve questões qualitativas. 0 planejamento ambiental urbano pode se beneficiar da abordagem da paisagem sonora, tratando da percepção do ambiente acústico no qual o som é considerado um recurso e não um desperdício.

A literatura evidencia avanços nos estudos de paisagem sonora, como a investigação de ferramentas práticas que auxiliem no planejamento urbano e gestão urbana, dentre estas, o mapeamento sonoro (Alleta et al., 2016; Valques, 2016; Jenning \& Cain, 2013). Mapas de ruído e paisagem sonora são ferramentas úteis para o planejamento de ações de mitigação, preservação e para a comunicação com os cidadãos (Margaritis \& Kang, 2017).

Estudos de mapeamento da paisagem sonora mesclaram dados quantitativos (medições e simulações acústicas) com dados qualitativos (tipos de fontes, entrevistas, relatório de percepção do ruído), criando mapas quantitativos e qualitativos (Vogiatzis \& Remy, 2017; Aletta \& Kang, 2015; Klaeboe et al., 2006; 
Margaritis \& Kang, 2017). Com esses estudos, obtiveram-se dados para identificação de áreas potenciais (sons agradáveis) e áreas críticas (ruidosas).

Diante do exposto, percebe-se uma lacuna nos estudos sobre mapeamento da paisagem sonora com inserção de fontes pontuais. Dessa forma, esta investigação pretende contribuir com a comunidade científica nos debates sobre a ferramenta de mapeamento para análise da paisagem sonora, neste estudo com foco em fontes pontuais, os sons religiosos, considerando, além de dados acústicos, a percepção humana.

De acordo com a problemática apresentada, sobre a proliferação dos sons religiosos na cidade contemporânea e o mapeamento da paisagem sonora, esta investigação foi desenvolvida na cidade de Maceió, capital de Alagoas, Brasil. Ao observar a base cartográfica da cidade de Maceió do ano 2000, percebeu-se um quantitativo considerável de espaços religiosos (Prefeitura Municipal de Maceió [PMM], 2000), destacando-se o loteamento Village Campestre, com dezessete templos, localizado no bairro Cidade Universitária, noroeste do tabuleiro. Ao atualizar o levantamento no ano 2014, o número de edificações religiosas aumentou para sessenta e, em 2016, para setenta e três. A alta densidade de espaços religiosos no loteamento foi um forte indicador para escolha deste local como objeto de estudo. Sendo assim, o objetivo desta investigação é analisar o impacto sonoro provocado por templos na paisagem sonora de uma área residencial por meio de mapeamento sonoro relacionado aos atributos quantitativos (níveis de pressão sonora) e perceptuais (agradabilidade e incômodo), a partir de medições e aplicações de questionário ${ }^{1}$.

\section{Paisagem sonora e mapeamento}

O ambiente sonoro pode refletir a ordem histórica, social, cultural, política e religiosa de um lugar em um espaço temporal. Assim, o ruído pode ser compreendido como um registro de vitalidade dentro da esfera cultural, principalmente, quando ocorre em espaços públicos (Labelle, 2010). Os sons de várias comunidades religiosas, no espaço urbano contemporâneo, refletem, constroem ou estimulam conflitos de relações sociopolíticas (Kovačič, 2018).

Truax (2001) enfatiza a relação positiva que pode ocorrer entre um som e uma comunidade, mas destaca que esta relação irá depender do perfil dos ouvintes. 0 som dos sinos da igreja, investigado por Kovačič (2018), possui uma carga de importância histórica e cultural e desempenha um papel comunicador, mas no contexto que está inserido, na rua em Ljubljana, capital da Eslovênia, não é bem aceito, pois a comunidade é composta, em sua maioria, por mulçumanos. A aceitação ou não de um som é um forte indicador de como as comunidades compartilham o espaço. Um som pode ser caracterizado como um marco sonoro quando é aceito pela comunidade, quanto a preponderância, individualidade e quantidade (Schafer, 1977).

Nos estudos de sons religiosos, a paisagem sonora tem sido uma abordagem de investigação que considera um conjunto de relações entre o ouvinte, o ambiente sonoro e a sociedade. Dessa forma, não são considerados apenas os parâmetros físicos do som, mas também os aspectos relevantes da percepção, bem como os aspectos culturais relacionados às interações sociais. Pesquisas evidenciam que a qualidade dos sons não está necessariamente ligada aos níveis de pressão sonora, outras variáveis como os descritores psicoacústicos são levados em consideração (ISO, 2018; Xiao \& Aletta, 2016).

A abordagem de paisagem sonora está sendo difundida para análises de ambientes urbanos. Sua metodologia é composta por trilhas sonoras, identificação de tipos de sons, medições dos níveis de pressão sonora, questionários e entrevistas (Kogan et al., 2018; Hedblom et al., 2017; Romero et al., 2016; Szeremeta \& Zannin, 2009).

Outra metodologia que vem sendo adotada nas análises de paisagem sonora é o mapeamento sonoro, uma ferramenta que possibilita a visualização da propagação do som, maior aprofundamento das análises e simulação de cenários. A adoção desta ferramenta é um avanço, visto que os estudos de mapas de ruído se concentram, principalmente, em fontes de ruído, como tráfego rodoviário, tráfego ferroviário, aeronaves e

${ }^{1}$ Esta pesquisa resultou em uma dissertação de mestrado em 2017. 
indústrias e não fornecem informações sobre sons agradáveis ou preferidos, como sons de água, canto de pássaros e farfalhar de árvores (Hong \& Jeon, 2017).

Os estudos de mapas de paisagens sonoras podem ser resumidos em três temas principais: o mapa da fonte sonora (identificação de fontes sonoras e distribuição de NPS), o mapa psicoacústico (parâmetros da psicoacústica como loudness) e o mapa de qualidade perceptual do ambiente sonoro (percepção das pessoas). 0 mapeamento da paisagem sonora, que descreve a percepção subjetiva das pessoas, é uma ferramenta útil, pois permite uma análise de caracterização da área (Aletta \& Kang, 2015; Ge et al., 2009; Liu et al., 2013; Liu et al., 2014; Liu et al., 2020).

0 mapeamento sonoro vem sendo difundido no Brasil, mas ainda é pouco explorado quanto à sua aplicação como ferramenta de análise para paisagem sonora. Seu uso está mais ligado à produção de mapas de ruídos, onde é apresentada a distribuição espacial dos níveis de pressão sonora. Como exemplo de mapeamento da paisagem sonora, Szeremeta \& Zannin (2015) analisaram a percepção dos praticantes de atividade física sobre a qualidade ambiental sonora dos parques públicos de Curitiba. Os mapas sonoros possibilitaram a visualização de áreas mais críticas próximas ao perímetro das vias de tráfego.

Na perspectiva de mapas de ruído, Mendonça et al. (2013), por meio de mapeamento sonoro, atribuíram classes de diferenciação dos níveis de pressão sonora em quadras urbanas pertencentes à mesma zona de ocupação, na cidade de São Carlos, São Paulo. A partir disso, foi possível identificar as quadras que necessitavam de ações de controle para a melhoria acústica.

Para os estudos de paisagem sonora, novas metodologias de mapeamento estão sendo exploradas, como a investigação desenvolvida na Grécia por Vogiatzis \& Remy (2017), em que os pesquisadores mesclaram dados quantitativos (medições e simulações acústicas) com dados qualitativos (tipos de fontes, entrevistas, relatório de percepção do ruído), criando mapas quantitativos e qualitativos. A partir disto, foram elaboradas ferramentas de ações para redução dos níveis de ruído nas áreas afetadas.

Pesquisadores têm investido em ferramentas para implementar as técnicas de mapeamento nos estudos de paisagem sonora, Kang et al. (2018) desenvolveram um modelo de implementação de mapeamento de paisagens sonoras em cidades inteligentes. Liu et al. (2020) criaram um software denominado Soundscape Analysis and Mapping System (SAMS), que permite aos usuários processar e analisar rapidamente grandes volumes de dados acústicos em ambiente geoespacial.

Hong \& Jeon (2017) desenvolveram um mapeamento de dados psicoacústicos como loudness e sharpness em Seoul, Coreia do Sul. Brambilla \& Pedrielli (2020) fizeram uma análise escopo para fornecer uma visão geral de benefícios e desvantagens do monitoramento participativo de ruído e mapeamento de paisagem sonora. Klaeboe et al. (2006) realizaram um estudo com mapas de impacto de ruído com informações voltadas à sensibilidade dos moradores locais, por meio de um indicador de incômodo. Aletta \& Kang (2015) realizaram uma triangulação de mapas de ruído (sons de veículos), mapas de som (água e canto dos pássaros) e mapas de paisagem sonora (respostas individuais quanto à qualidade sonora), a fim de obter camadas difusas de informação e resultar na interpretação do ambiente acústico. Percebe-se que a maioria das análises utilizaram softwares pagos para a elaboração dos mapas, porém, Brito et al. (2018) avaliaram a precisão de algoritmos matemáticos disponíveis na literatura, sem custos, para o cenário brasileiro.

0 avanço nos estudos sobre o mapeamento da paisagem sonora poderá trazer benefícios para o planejamento e gestão dos espaços urbanos, pois é uma ferramenta facilitadora de comunicação entre os planejadores e a comunidade, além de possibilitar uma análise mais profunda e detalhada do ambiente sonoro.

\section{Metodologia}

Para a elaboração deste trabalho, foi adotado o método misto (quantitativo e qualitativo) aplicado a um estudo de caso. A seguir serão descritas as cinco etapas metodológicas de acordo com a ordem de execução. 


\section{Levantamento dos templos}

Os levantamentos de dados dos templos no loteamento Village Campestre aconteceram em dois momentos. 0 primeiro foi em 2014, para atualização os dados da base cartográfica de Maceió, e o segundo em 2016 para atualização dos dados levantados em 2014.

Nas duas fases de levantamentos, foi adotado o mesmo processo metodológico. Sendo ele: quatro visitas in loco, onde os templos identificados foram fotografados, mapeados e classificados quanto ao tipo e religião. Após a identificação dos templos, foi determinado um recorte da área com maior concentração de espaços religiosos para realizar as medições acústicas, entrevistas e mapeamento sonoro.

O loteamento Village Campestre está situado no bairro Cidade Universitária, que possui 71.441 habitantes (IBGE, 2010), noroeste da cidade de Maceió, capital alagoana do nordeste brasileiro. A área do loteamento é de aproximadamente 263 hectares (Figura 1).

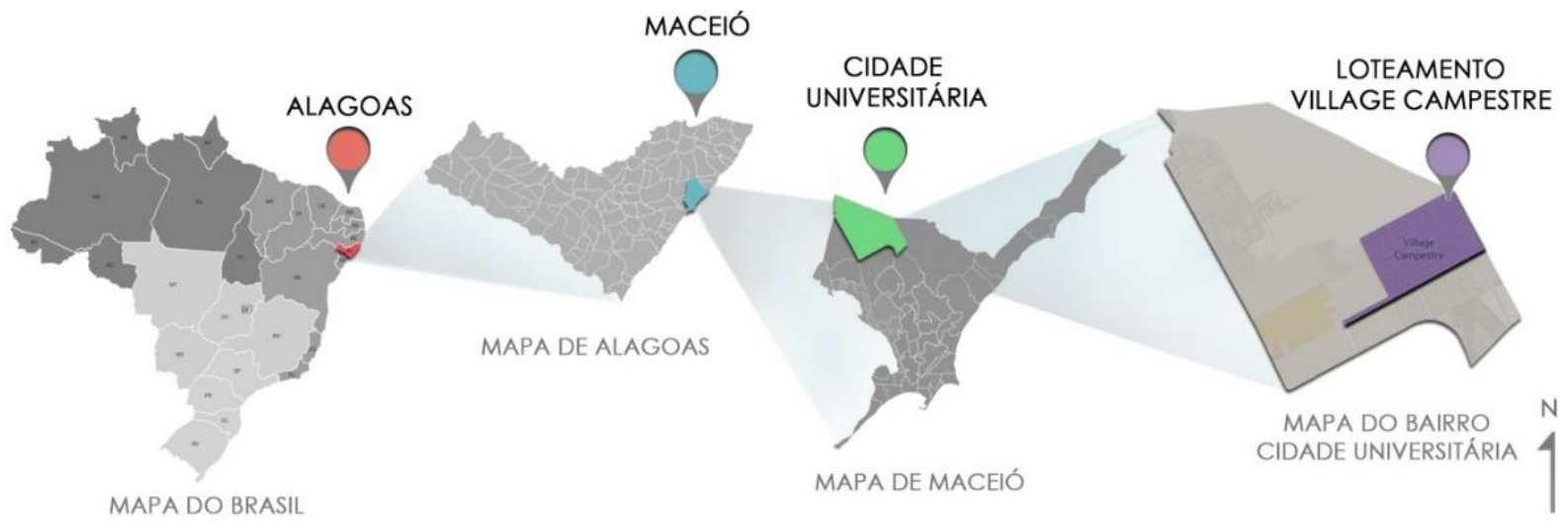

Figura 1 - Localização do estudo de caso, loteamento Village Campestre, Maceió, Alagoas. Fonte: Autores (2017).

O Village Campestre faz parte da Zona Residencial 2, é uma área de classe média baixa, onde mais da metade da população é composta por pessoas sem rendimentos mensais e com rendimento de até dois salários mínimos (IBGE, 2010). As ruas principais possuem uso misto e as vias secundárias, uso dominantemente residencial (Figura 2). Apesar de o loteamento ser classificado como zona residencial, após o estudo de uso e ocupação do solo, foi adotada a classificação "área mista predominantemente residencial" de acordo com a tabela para limites de níveis de pressão sonora por tipos de áreas habitadas da NRB 10151:2019 (ANBT, 2019).

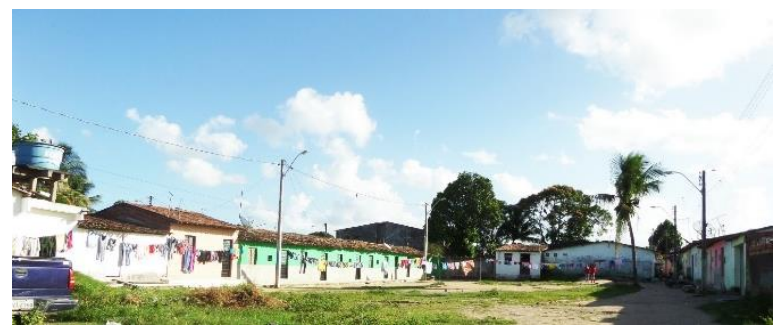

(a)

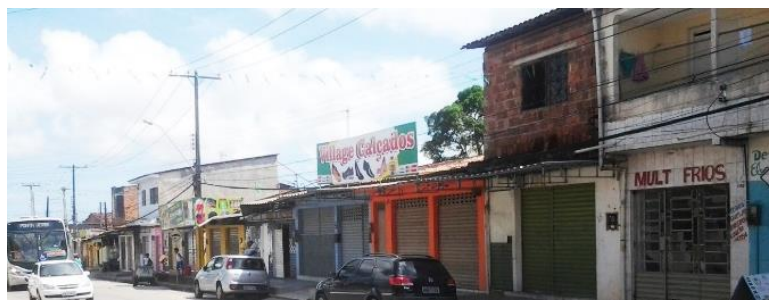

(c)

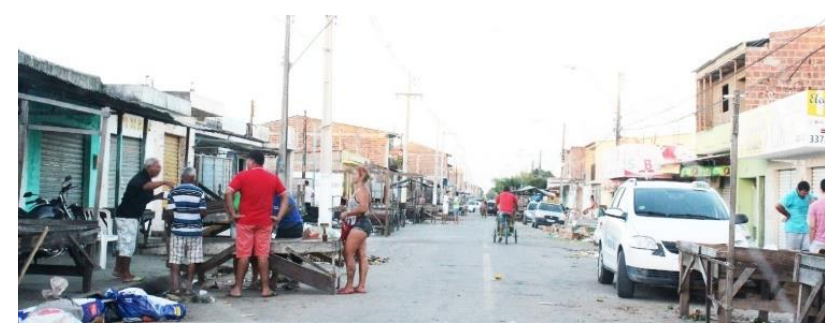

(b)

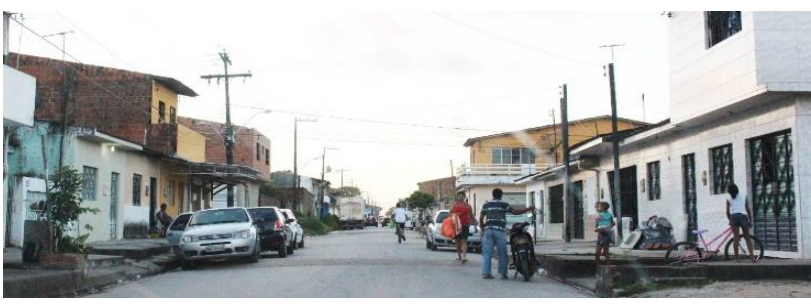

(d)

Figura 2 - Fotos do loteamento Village Campestre. (a e d) Área residencial, (b) área de uso misto, (c) área predominantemente comercial. Fonte: Autores (2017). 


\section{Medições acústicas}

As medições acústicas foram realizadas in loco, de acordo com os procedimentos sugeridos pela NBR 10151 - Avaliação do Ruído em Áreas Habitadas Visando o Conforto da Comunidade (ABNT, 2019). As medições dos LAeq, $\mathrm{T}^{2}$ (nível de pressão sonora contínuo equivalente ponderada em A e integrado em um intervalo de tempo T), no espectro global, ponderado em A, no método simplificado ${ }^{3}$, foram realizadas em pontos posicionados próximos às fontes sonoras (os templos). Os procedimentos de medições foram realizados no turno noturno, das $18 \mathrm{~h}$ às $22 \mathrm{~h}$, com duração de 5 minutos em cada ponto, com e sem o funcionamento dos espaços religiosos. Durante as medições foram contabilizados os veículos por tipo, grande porte (ônibus e caminhão), médio porte (carros) e pequeno porte (motocicletas).

0 equipamento adotado foi o medidor de pressão sonora da $01 \mathrm{~dB}$ - Metravib Solo, classe $1^{4}$, com microfone modelo MCE 2015 e calibrador CAL 3009000. 0 equipamento atende aos critérios da IEC $61672^{5}$. Para realizar as medições o equipamento foi calibrado assim como é exigido pela ABNT 10151:2019. Além da calibração com o calibrador do próprio aparelho, antes das medições, foi realizada uma calibração no software Solo 01dB Bati 32. Ainda segundo a Norma, o equipamento foi posicionado em um tripé a 1,20 m do piso e com distância mínima de $2 \mathrm{~m}$ do limite da edificação. Como a medição aconteceu em ambiente externo, ao ar livre, foi utilizado o protetor de vento acoplado ao microfone, como é exigido pela normativa. Foram descartados resultados de medição de nível sonoro afetados por sons intrusivos ${ }^{6}$.

\section{Mapeamento do NPS por simulação computacional}

O cálculo dos mapas sonoros foi desenvolvido por meio de simulações computacionais com o software Computer Aided Design Noise Abatement (CADNA-A) (Datakustik, 2012) versão 4.4. As simulações foram realizadas em dois cenários, sem o funcionamento dos templos, no período diurno, com medições realizadas em um intervalo das $10 \mathrm{~h}$ às $15 \mathrm{~h}$, e com o funcionamento dos templos, no período noturno, em um intervalo das $18 \mathrm{~h}$ às $22 \mathrm{~h}$. As metodologias da retícula ${ }^{7}$ e das zonas específicas foram aplicadas para elaboração dos mapas.

Foi elaborado um modelo em três dimensões mais próximo possível da realidade quanto a topografia e volumetria das edificações. Para isso, foi utilizada a Base Cartográfica de Maceió (PMM, 2000) e exportada do programa AutoCad (Autodesk, 2016) para o Cadna-A (Datakustik, 2012) em modelo dxf. Foi adotada uma altura média de três metros para as edificações modeladas, visto que as edificações locais variam de um a dois pavimentos.

As camadas do modelo foram configuradas no Cadna-A (Datakustik, 2012), a partir da identificação de vias, edificações e fontes sonoras pontuais (templos). Posteriormente, os receptores sonoros foram posicionados e, por fim, foi calculado o modelo. Os dados de entrada, configurados no programa, foram sistematizados na Tabela 1.

\footnotetext{
2 Nível de pressão sonora contínuo equivalente ponderada em A no espectro global, obtido por integração no tempo T. Esse descritor é necessário para avaliação sonora ambiental em ambientes externos e internos a edificações (ABNT, 2019).

30 método simplificado é utilizado para medição do nível de pressão sonora global, em ambientes externos ou internos às edificações, para identificação e caracterização de sons contínuos ou intermitentes (ABNT, 2019).

4 É um instrumento que possibilita maior precisão nos resultados.

5 IEC 616772-1, Electroacoustics - Sound level meters - Part 1: Specifications.

6 Som intrusivo é definido como interferência sonora alheia ao objeto de medição (ABNT, 2019).

${ }^{7}$ A metodologia da retícula corresponde a uma trama com medidas proporcionais à área, em cujos nodos são colocadas estações de medições (Mardones, 2009).
} 
Tabela 1 - Dados de entrada para simulação computacional no software Cadna-A

\begin{tabular}{ll}
\hline \multicolumn{2}{c}{ Dados de entrada para simulação - Cadna-A versão 4.4 } \\
Parâmetros & Valores inseridos no software \\
\hline Norma emissão rodoviária & RLS 90 \\
Norma propagação sonora & 1509613 \\
Coeficiente de incerteza de propagação & $3^{*} \log 10(\mathrm{~d} / 10)^{8}$ \\
Malha de cálculo & $1 \times 2 \mathrm{~m}$ \\
Malha por área & 5 \\
Número de reflexões & 1 \\
Coeficiente de absorção do solo & 0,20 \\
Coeficiente de absorção das edificações & 0,21 \\
Pavimento da Rodovia & Estritamente RLS-90 \\
Interpolação do Grid & $9 * 9$ \\
Altura do receptor & $1,20 \mathrm{~m}$ \\
Espaçamento do receptor & $2,0 \times 2,0 \mathrm{~m}$ \\
Distância máxima receptor - receptor & $10.000,0 \mathrm{~m}$ \\
Distância mínima fonte - receptor & $2,0 \mathrm{~m}$ \\
Temperatura média & $30^{\circ} \mathrm{C}$ \\
Umidade relativa & $80 \%$ \\
\hline
\end{tabular}

Fonte: Autores (2017).

Foram adotadas as normas padrões do software Cadna-A (Datakustik, 2012), a malha de cálculo de 1x2 $\mathrm{m}^{9}$ para obter maior precisão dos resultados e adotados os valores do coeficiente de absorção sonora que melhor retratavam o cenário construído (superfície lisa e rígida como o concreto). A altura do receptor foi de 1,20 m, a mesma adotada nas medições acústicas de cinco minutos de duração, com distância mínima da fonte e receptor de 2,0 m, ambos recomendados pela NBR 10151 (ABNT, 2019). Foram considerados os valores de temperatura média e umidade relativa dos dados climáticos da cidade de Maceió (Tabela 1).

\section{Avaliação qualitativa dos moradores locais}

Essa etapa da pesquisa constitui-se a partir da metodologia proposta por Kang (2007), baseada na análise da percepção sonora de pessoas de um determinado lugar. Foi elaborado um questionário com perguntas subjetivas, objetivas de duas escolhas (sim ou não) e objetivas de múltipla escolha. As questões tinham o objetivo de investigar as relações dos moradores com o lugar e os sons advindos dos templos.

Para as perguntas de múltipla escolha, foi utilizada a escala de Likert que mede atitudes de comportamento, utilizando opções de respostas que variam de um extremo a outro. 0 questionário foi composto por perguntas ordenadas que foram respondidas de forma objetiva pelo informante (Tabela 2).

\footnotetext{
8 Sendo "d" a distância determinada para interpolação dos dados, neste caso d corresponde a 9.

${ }^{9}$ Esta dimensão de malha foi adotada para obter maior precisão do modelo; por ser uma área pequena, é válido um refino para verificar os NPS em pontos de interesse.
} 
Tabela 2 - Questionário

\begin{tabular}{|c|c|c|c|c|c|c|}
\hline \multicolumn{7}{|c|}{ Dados do entrevistado } \\
\hline \multicolumn{3}{|l|}{ Idade: } & \multicolumn{4}{|c|}{$\begin{array}{l}\text { Religião: } \\
\text { Endereço: }\end{array}$} \\
\hline \multicolumn{7}{|l|}{ Percepção sonora } \\
\hline \multicolumn{3}{|c|}{ 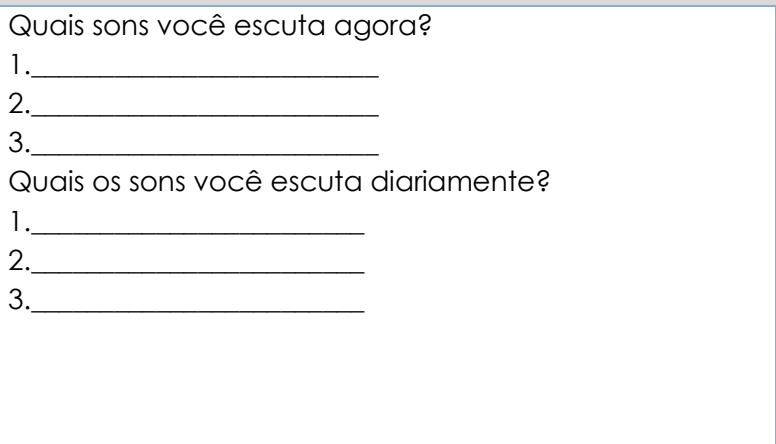 } & \multicolumn{4}{|c|}{$\begin{array}{l}\text { Existe algum som do loteamento que o incomode? } \\
\text { Sim Não } \\
\text { Se sim, qual? } \\
\text { Existe algum som que o agrade no loteamento? } \\
\text { Sim Não } \\
\text { Se sim, qual? }\end{array}$} \\
\hline \multicolumn{7}{|c|}{ Qual edificação faz mais barulho no loteamento? } \\
\hline Residências & Igrejas & Escolas & Bares & Con & & Outros \\
\hline \multicolumn{7}{|l|}{ Os sons da fé } \\
\hline \multicolumn{7}{|c|}{ Os sons produzidos pelas igrejas são: } \\
\hline Muito agradável & Agradável & Adequado & & gradável & & desagradável \\
\hline \multicolumn{7}{|c|}{ Os sons produzidos pelas igrejas são: } \\
\hline Muito alto & Alto & Adequado & & Baixo & & Ivito baixo \\
\hline
\end{tabular}

Fonte: Autores (2017).

Cada dado coletado atendeu a uma justificativa de análise para este trabalho. Os dados sobre religião foram abordados para relacionar a religião dos entrevistados com as perguntas que tratam das igrejas. 0 endereço serviu para situar as respostas nos mapas perceptivos. As perguntas sobre a percepção dos sons locais foram fundamentais para identificar os sons percebidos pelos moradores e para compreender os sons positivos e/ou negativos do lugar. Para isso, foram anotados os três primeiros sons respondidos pelos moradores. E, por fim, há a pergunta sobre os sons dos templos, substancial para a análise.

O questionário foi aplicado no período diurno, durante dois dias da semana, alcançando uma amostra de cinquenta entrevistados. 0 público-alvo foi pessoas que transitavam pela rua, identificados como moradores locais.

As respostas foram sistematizadas no software Excel (Microsoft, 2016), em um banco de informações que possibilitou ao pesquisador cruzar os dados, como, por exemplo, investigar a religião do entrevistado que percebe os sons das igrejas como agradáveis.

\section{Mapeamento perceptivo}

Os mapas perceptivos foram criados a partir da Base Cartográfica de Maceió, onde foram situados ícones georreferenciados de acordo com as respostas sobre percepção sonora e endereço do entrevistado. A fim de situar geograficamente as respostas sobre o ambiente sonoro. 


\section{Análise dos resultados}

\section{Os templos}

O primeiro registro do quantitativo de templos no loteamento Village Campestre foi da Base Cartográfica de Maceió ano 2000, no qual o mapa apontava dezessete templos. Em 2014, foi realizado o primeiro levantamento dos templos no loteamento, estiveram quantificados sessenta templos. 0 número mais que triplicou quando comparado ao quantitativo do ano 2000. Em 2016, foi realizado mais um levantamento, que quantificou setenta e três templos, um crescimento de $22 \%$ em dois anos. Foram identificadas as edificações religiosas que permaneceram, mudaram de nome, fecharam, e os novos templos (Figura 3).

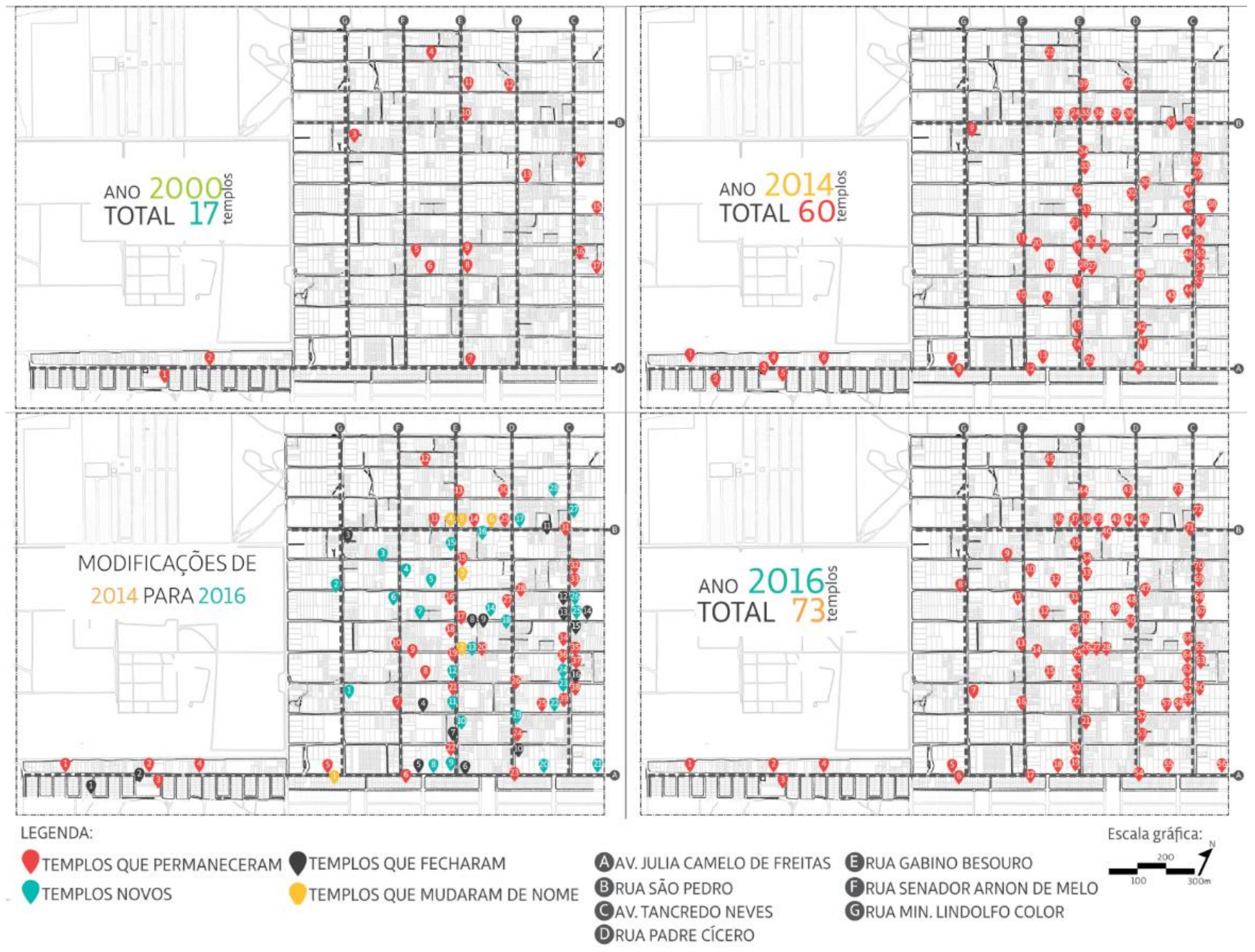

Figura 3 - Mapa com localização e quantitativo de templos no Loteamento Village Campestre: ano 2000; ano 2014; modificações sofridas de 2014 para 2016; e ano 2016. Fonte: Autores (2017).

Ao analisar o levantamento fotográfico dos templos, é possível notar semelhança nas características físicas das edificações (Figura 4). Os templos estão, em sua maioria, instalados em edificações adaptadas, destinadas aos usos residenciais e comerciais. A adaptação de uso sem o devido tratamento acústicos pode acarretar a propagação dos sons originados na edificação para os arredores. Dos setenta e três templos identificados, nenhum possuía tratamento acústico, como condicionamento acústico e isolamento sonoro. O interesse das comunidades religiosas estava detido na amplificação eletroacústica do som, pois, dessa forma, encontra-se um meio para levar a palavra de Deus para além dos limites das edificações, e assim conquistar novos fiéis. 


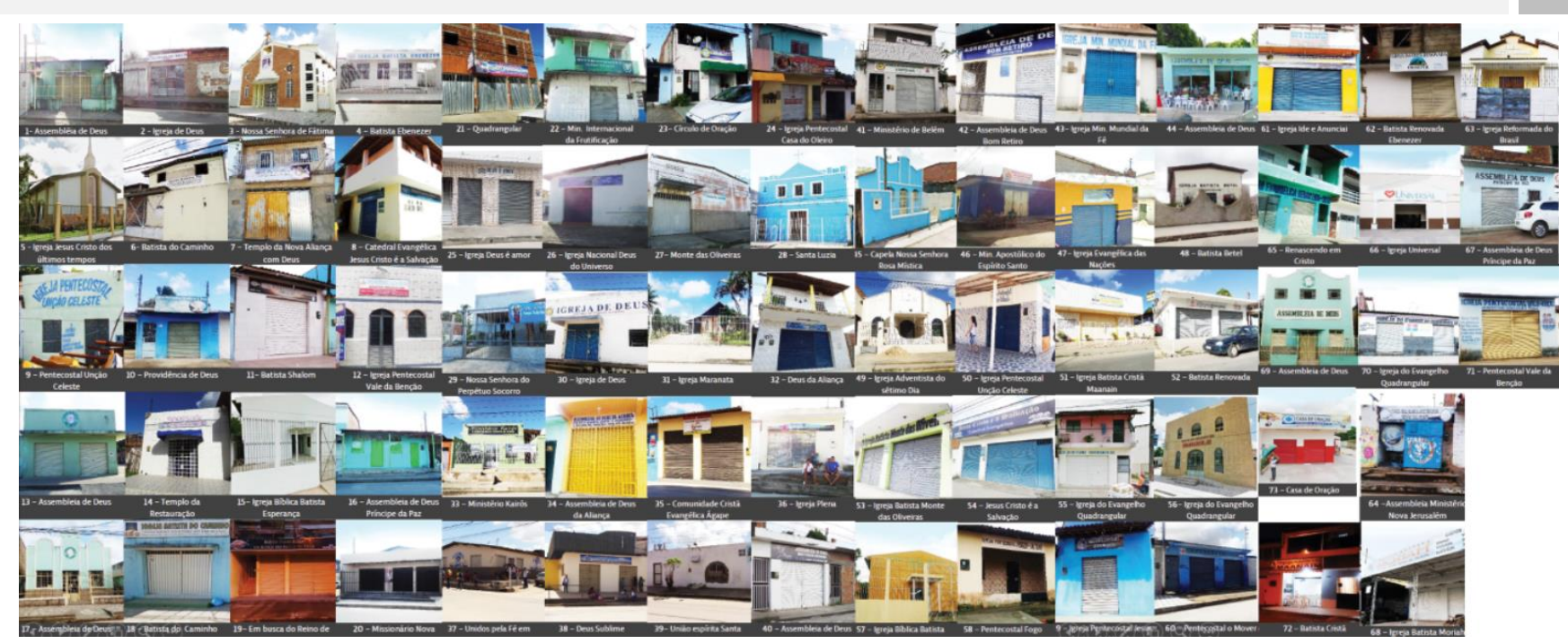

Figura 4 - Fotografias dos templos registrados no ano de 2016. Fonte: Autores (2017).

A apropriação dos templos no loteamento é dinâmica; em muitos casos, efêmera. Durante a pesquisa, alguns templos fecharam e outros abriram ou mudaram de nome. Esse fator pode ser consequência das "facilidades" para o funcionamento da igreja. Por meio do estudo da legislação existente, foi possível compreender que não há burocracia para abrir uma igreja, e que na maioria dos casos o registro é feito como empresa. Ressaltam-se ainda dois fatores facilitadores: a inexistência de um órgão fiscalizador e a facilidade de adequar edificações previamente existentes para o uso religioso (Oliveira, 2017; Maceió, 2007).

A partir do levantamento, nota-se a proximidade entre os templos, como a Figura 5, que apresenta igrejas vizinhas de diferentes religiões, evidenciando o conflito de fontes sonoras pontuais.

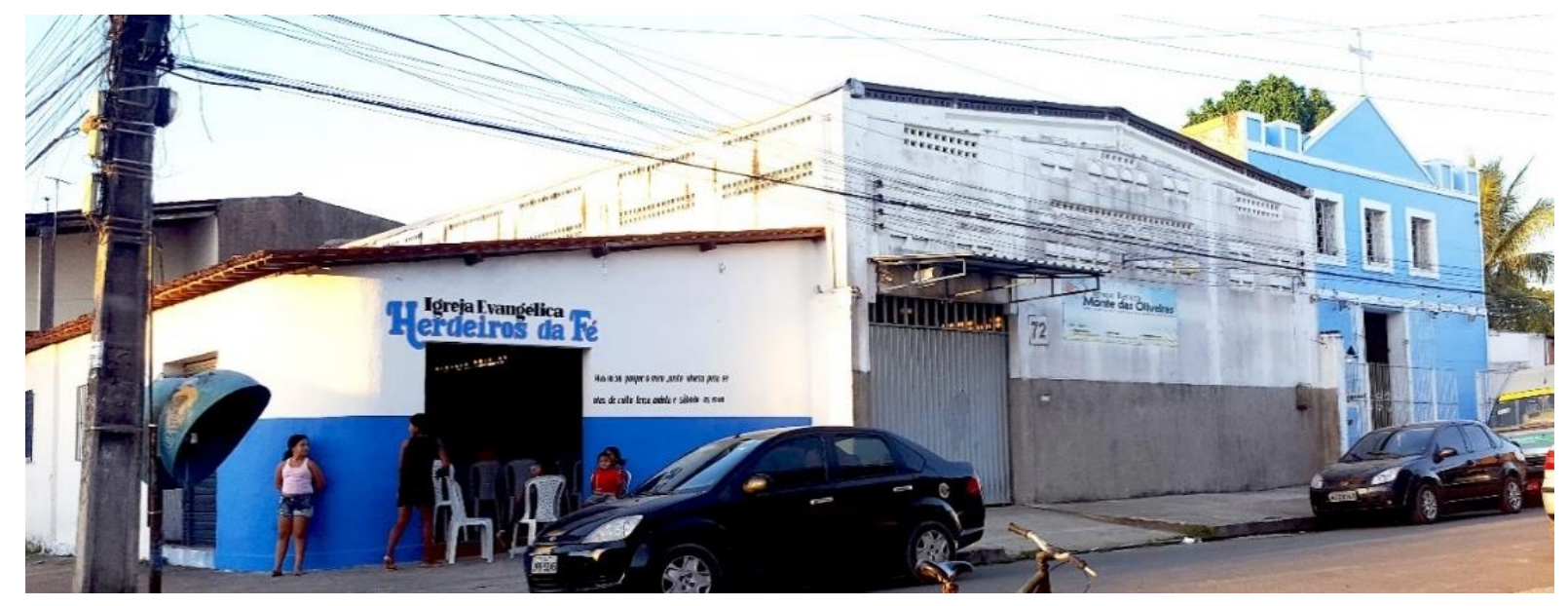

Figura 5 - Proximidade dos templos. Da esquerda para direita: igreja evangélica HF ao lado da igreja Batista MO, ao lado da igreja católica SL. Fonte: Autores (2017).

Na Figura 6, pode-se verificar que mais de noventa por cento dos templos são de religião evangélica, apenas $5 \%$ de católicas e $2 \%$ de umbanda. No que se refere aos templos da religião evangélica do loteamento, eles se classificam em mais de sete tipos de denominações (Figura 6). 

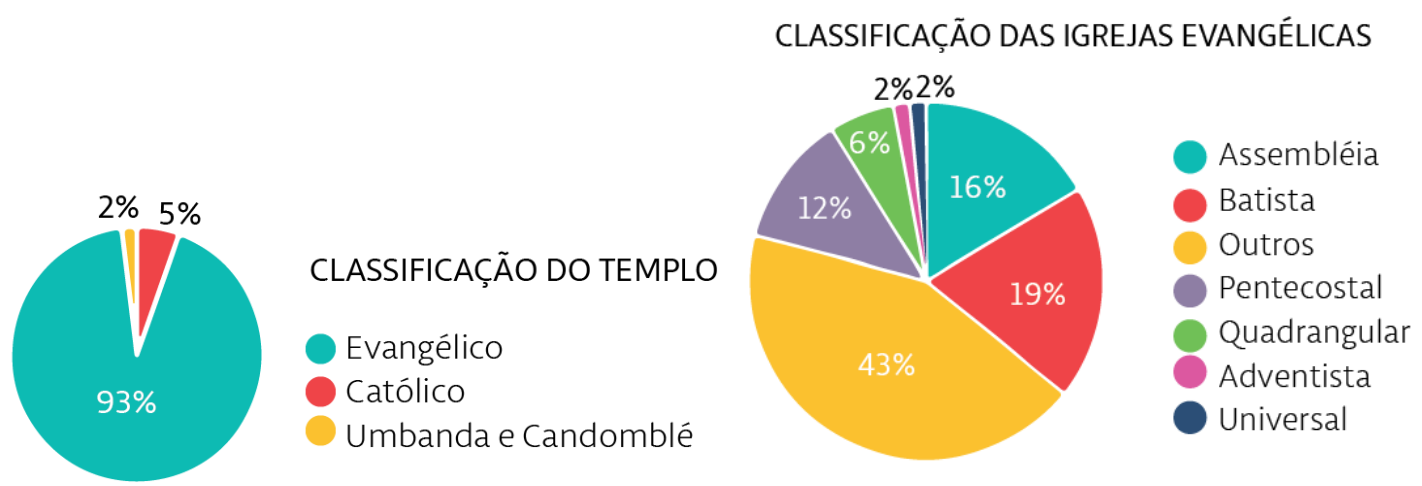

Figura 6 - Classificação de religiões dos templos no Loteamento Village Campestre. Fonte: Autores 2017).

\section{Mapeamento sonoro numérico - noturno fontes pontuais}

Para avaliar o impacto sonoro do conjunto de templos no loteamento Village Campestre, foram selecionados 32 templos, os quais estavam funcionando simultaneamente (Figura 7). A amostragem corresponde a aproximadamente $70 \%$ dos templos do recorte. Na Tabela 3 são apresentados os valores de LAeq,T medidos em frente às igrejas, no turno noturno, com e sem celebrações. Para evitar a identificação direta, foram adotadas siglas com as iniciais dos nomes das igrejas.
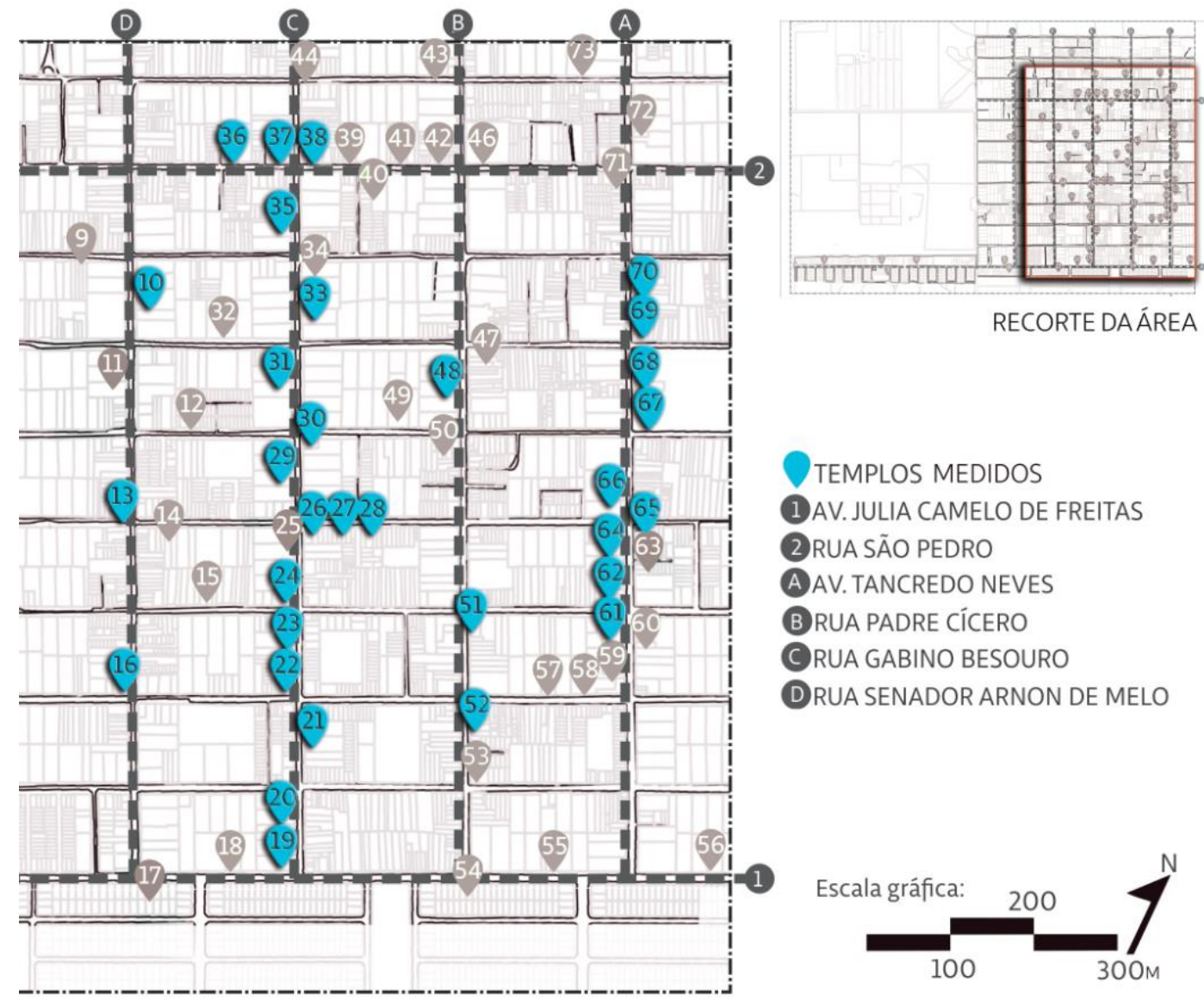

RECORTE DAÁREA

TEMPLOS MEDIDOS

1)AV. JULIA CAMELO DE FREITAS

2 RUA SÃO PEDRO

A AV. TANCREDO NEVES

B RUA PADRE CÍCERO

C RUA GABINO BESOURO

DRUA SENADOR ARNON DE MELO

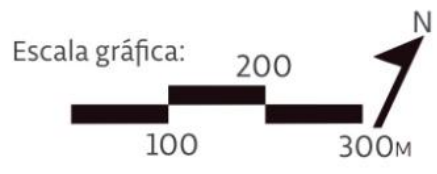

Figura 7 - Templos com funcionamentos simultâneos selecionados para as medições dos LAeq,T. Fonte: Autores (2017). 


\section{Mapeamento da paisagem sonora}

Tabela 3 - Dados de localização, identificação e LAeq,T dos templo com e sem funcionamento no período noturno.

\begin{tabular}{|c|c|c|c|}
\hline \multicolumn{4}{|c|}{ Medições acústicas noturnas em frente aos templos } \\
\hline \multirow[t]{4}{*}{ Localização } & Templo & Sem celebrações & Com celebrações \\
\hline & & LAeq, T dB $(A)$ & LAeq, $T$ dB $(A)$ \\
\hline & & NBR 10151 & NBR 10151 \\
\hline & & $50 \mathrm{~dB}(\mathrm{~A})$ & $50 \mathrm{~dB}(\mathrm{~A})$ \\
\hline Rua Senador Arnon de Melo & 10. IPD & 58,7 & 68,3 \\
\hline \multirow[t]{2}{*}{ Rua D } & 13. $A D$ & 59,8 & 71,2 \\
\hline & 16. ADPP & 55,0 & 68,1 \\
\hline Rua Gabino Besouro & 19. IBRD & 51,4 & 85,7 \\
\hline \multirow[t]{16}{*}{ Rua C } & 20. MNA & 53,6 & 82,1 \\
\hline & 21. Q & 56,6 & 80,1 \\
\hline & 22. MIF & 54,9 & 72,0 \\
\hline & 23. $\mathrm{CO}$ & 51,8 & 72,8 \\
\hline & 24. IPCO & 52,5 & 71,6 \\
\hline & 26. INDU & 58,9 & 71,1 \\
\hline & 27. $\mathrm{MO}$ & 59,7 & 71,3 \\
\hline & 28. ISL & 59,1 & 73,2 \\
\hline & 29. INPS & 56,8 & 70,0 \\
\hline & 30. ID & 59,7 & 75,1 \\
\hline & 31. IM & 49,5 & 70,4 \\
\hline & 33. MK & 52,8 & 75,1 \\
\hline & 35. CCEA & 63,7 & 73,4 \\
\hline & 36. IP & 57,8 & 82,8 \\
\hline & 37. UFA & 50,5 & 73,0 \\
\hline & 38. DS & 52,3 & 74,9 \\
\hline Rua Padre Cícero & 48. $B B$ & 50,1 & 72,9 \\
\hline \multirow[t]{2}{*}{ Rua B } & 51. IBCM & 50,8 & 69,7 \\
\hline & 52. BR & 57,3 & 78,5 \\
\hline Avenida Tancredo Neves & 61. IIA & 62,4 & 82,5 \\
\hline \multirow[t]{8}{*}{ Rua A } & 62. BRE & 63,9 & 79,4 \\
\hline & 64. IRB & 62,6 & 78,9 \\
\hline & 65. RC & 52,5 & 61,2 \\
\hline & 66. IU & 60,8 & 78,1 \\
\hline & 67. ADPP & 62,0 & 76,7 \\
\hline & 68. IBM & 62,9 & 78,8 \\
\hline & 69. AD & 65,7 & 75,8 \\
\hline & 70. IQ & 63,2 & 78,7 \\
\hline
\end{tabular}

Fonte: Autores (2017).

A partir da análise das medições, percebe-se que nos dois cenários noturnos, os LAeq,T estão acima de $50 \mathrm{~dB}(\mathrm{~A})$, ultrapassando o valor recomendado pela NBR 10151 (ABNT, 2019). No turno noturno sem funcionamento dos templos apenas 30\% das edificações apresentaram valores dos NPS próximos ao recomendado pela Norma, enquanto os demais pontos tiveram valores superiores, chegando a uma diferença de até $15 \mathrm{~dB}(\mathrm{~A})$. Os valores de NPS medidos durante as celebrações religiosas ultrapassaram até $35 \mathrm{~dB}(\mathrm{~A})$ do valor recomendado, mais que o dobro da situação anterior. Não há influência significativa dos veículos nas medições noturnas devido ao baixo quantitativo, quando comparado ao quantitativo diurno.

As diferenças entre os NPS com e sem funcionamento dos templos foram positivas em todos os casos medidos, com mínimo de $8 \mathrm{~dB}(\mathrm{~A})$ e máximo de $30 \mathrm{~dB}(\mathrm{~A})$. Para melhor visualização, os dados acústicos medidos no período noturno em frente aos templos (com e sem funcionamento) foram sistematizados, em mapas com escalas de cores correspondentes aos NPS locais (Figura 8). Estes mapas foram produzidos de 
forma manual, no programa de vetorização, Illustrator (Adobe, 2012), a fim de mostrar os valores de LAeq,T medidos em frente aos templos.
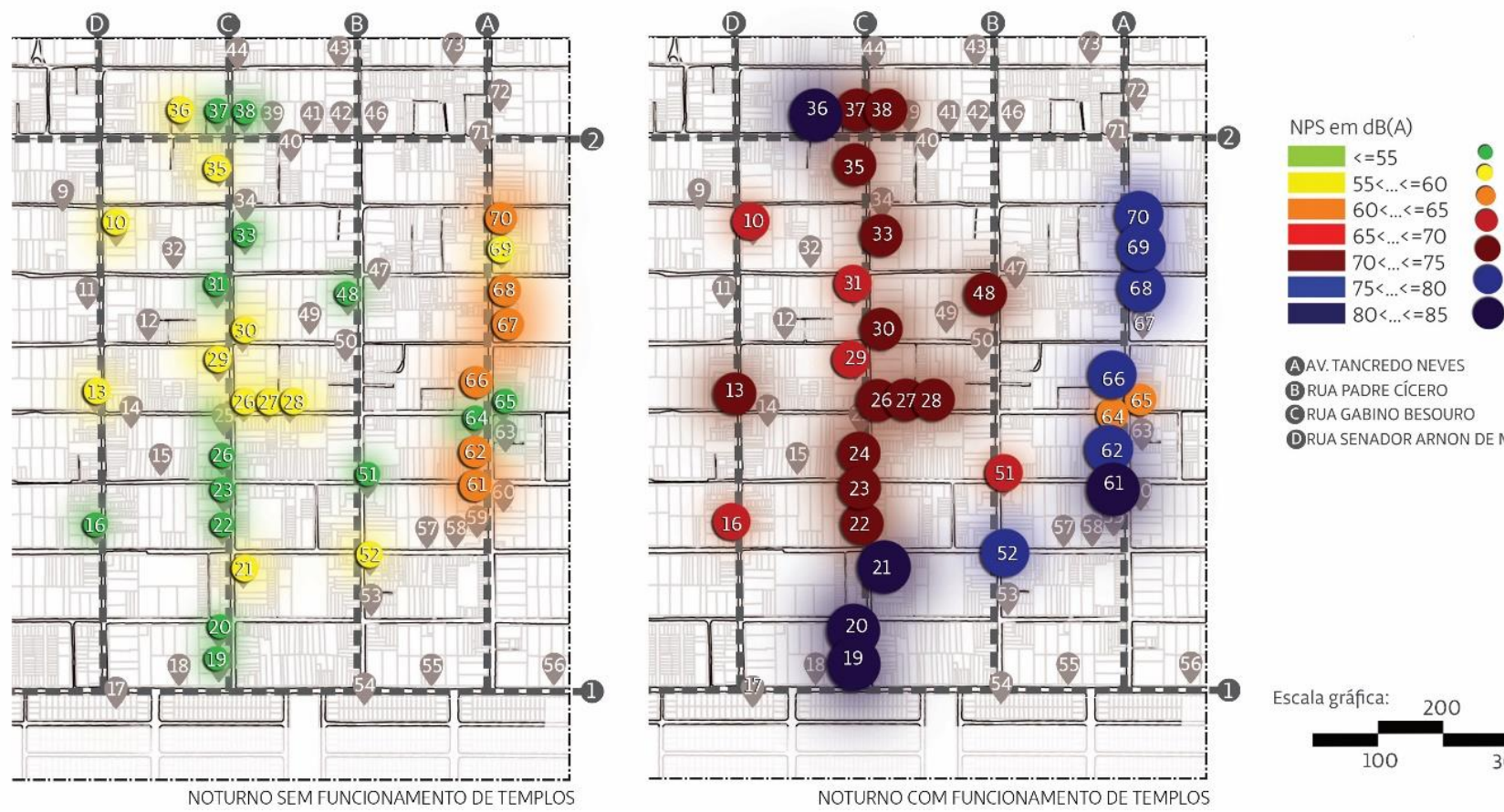

AAV. TANCREDO NEVES

B RUA PADRE CÍCERO

CRUA Gabino besouro

DRUA SENADOR ARNON DE MELO

Figura 8 - Valores medidos dos LAeq, T a noite, no exterior e em frente às igrejas, sem e com o funcionamento dos templos.

Fonte: Autores (2017).

\section{Mapeamento sonoro numérico - diurno e noturno}

Para a análise do ambiente sonoro, considerando as demais fontes sonoras distintas das igrejas, foi realizada a simulação computacional. Foram utilizados dois cenários para compreender o ambiente sonoro: o diurno (10h às $15 \mathrm{~h}$ ) sem funcionamento dos templos, e o noturno (18h às $22 \mathrm{~h}$ ) com funcionamento dos templos. Para isto, novas medições foram realizadas em pontos definidos por uma malha de $200 \times 200 \mathrm{~m}$. Os valores foram sistematizados no mapa elaborado manualmente, junto com a contagem de veículos realizada em cada ponto de medição (Figura 9 e Tabela 4).

Tabela 4 - Número de veículos contabilizados durante as medições acústicas.

\begin{tabular}{|c|c|c|c|c|c|c|c|c|c|c|c|c|c|c|c|c|c|c|c|c|}
\hline \multicolumn{21}{|c|}{ Quantitativo de veículos durante as medições acústicas } \\
\hline & \multicolumn{20}{|c|}{ Pontos de medições acústica } \\
\hline & 1 & 2 & 3 & 4 & 5 & 6 & 7 & 8 & 9 & 10 & 11 & 12 & 13 & 14 & 15 & 16 & 17 & 18 & 19 & 20 \\
\hline Dia & 10 & 12 & 5 & 12 & 8 & 7 & 9 & 25 & 6 & 10 & 11 & 15 & 4 & 20 & 12 & 15 & 38 & 45 & 41 & 10 \\
\hline Noite & 1 & 3 & 0 & 2 & 3 & 1 & 1 & 3 & 4 & 0 & 3 & 3 & 2 & 1 & 3 & 6 & 1 & 2 & 2 & 3 \\
\hline
\end{tabular}

Fonte: Autores (2021). 

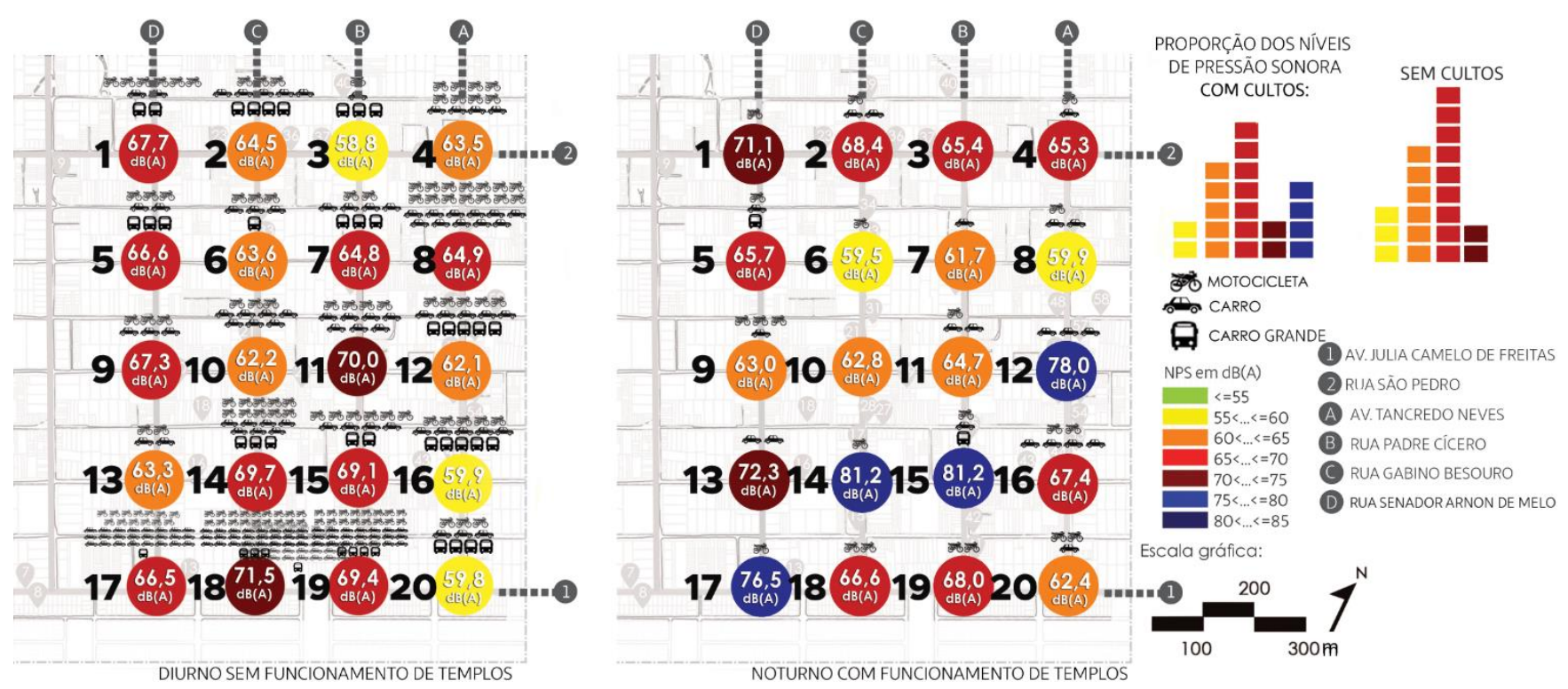

Figura 9 - Valores medidos dos LAeq, T, nos pontos determinados na malha de $200 \times 200 \mathrm{~m}$, no turno diurno (sem funcionamento dos templos) e noturno (com funcionamento dos templos). Fonte: Autores (2017).

A simulação computacional foi realizada a partir dos dados de LAeq,T medidos nos pontos determinados pela malha e nos pontos localizados em frente aos templos. Os valores medidos serviram como dados de entrada para a configuração do modelo no programa Cadna-A (Datakustik, 2012). Com os mapas sonoros, foi possível visualizar a propagação do som diurna e noturna no loteamento.

A Figura 10 apresenta os mapas sonoros simulados, o primeiro diurno sem funcionamento dos templos (SFT), e o segundo noturno com funcionamento dos templos (CFT). No mapa SFT, percebem-se níveis de pressão sonora mais elevados próximos às principais ruas, isto devido ao ruído ocasionado pelos veículos, fonte sonora predominante. No mapa CFT, os templos são fontes sonoras predominantes.

No mapa SFT, nota-se que as manchas variam do verde (menor que $55 \mathrm{~dB}(\mathrm{~A})$ ) ao vermelho (entre $65 \mathrm{e}$ $70 \mathrm{~dB}(\mathrm{~A})$ ). As ruas A, B, C e D possuem fluxo moderado de carros com velocidade média de $40 \mathrm{~km} / \mathrm{h}$; uma parcela significativa dos fluxos é realizada a pé e de bicicleta. A rua B concentra os trechos mais ruidosos, isto por causa do tráfego intenso e por ser corredor de ônibus.

No mapa CFT, as edificações religiosas foram configuradas como fontes sonoras pontuais. Estas foram posicionadas no modelo como receptores nos pontos equivalentes às medições in loco. No mapa simulado, há manchas azuis nas áreas próximas aos templos, que representa valores de NPS próximo de $80 \mathrm{~dB}(\mathrm{~A})$. Os sons oriundos dos templos se espalham na circunvizinhança, nos valores de 60 a $65 \mathrm{~dB}(\mathrm{~A})$. As ruas A e $\mathrm{C}$ foram as mais afetadas com a propagação desses sons, justamente por apresentarem maior concentração de edificações religiosas. Dependendo da intensidade do som proveniente dos templos, a propagação sonora pode gerar sobreposição de sons, como foi o caso das ruas A e B. 

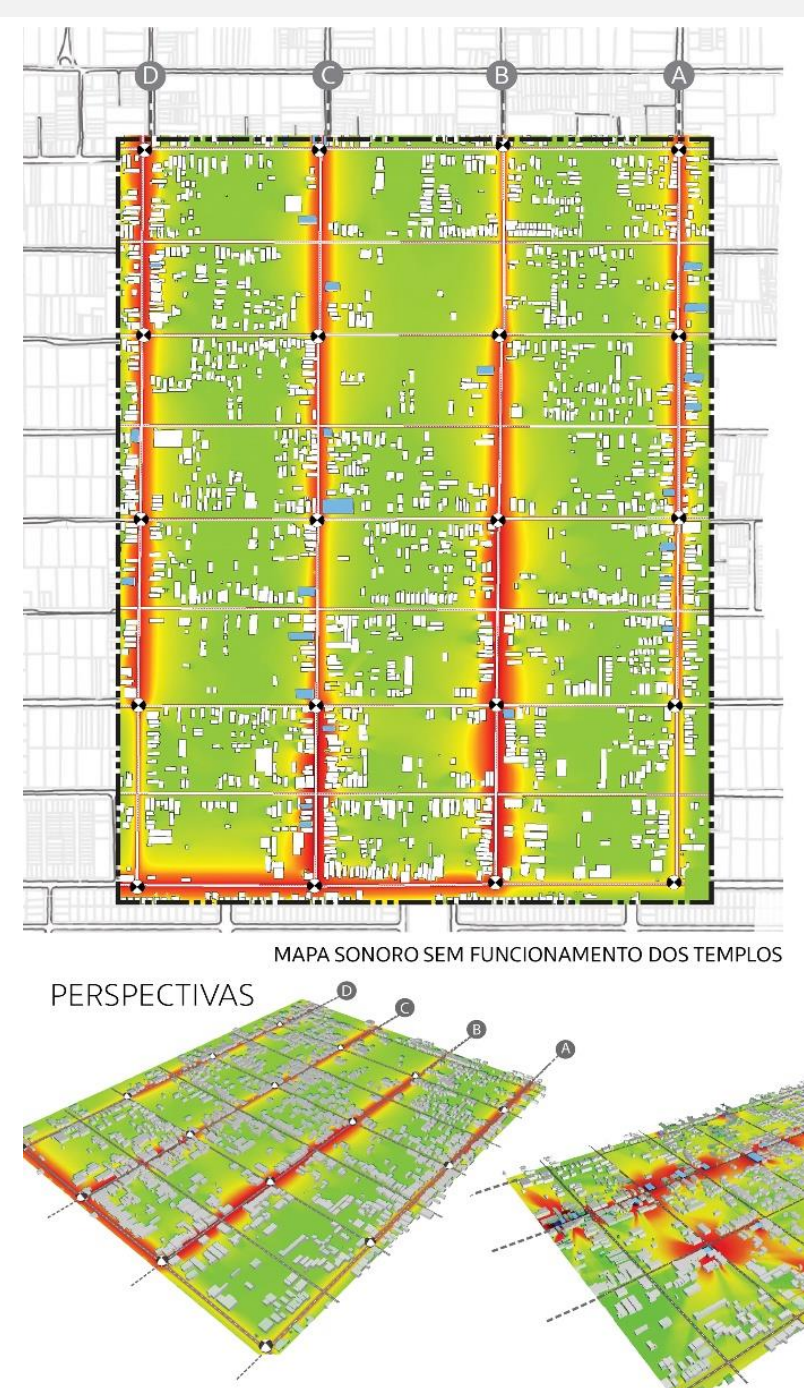

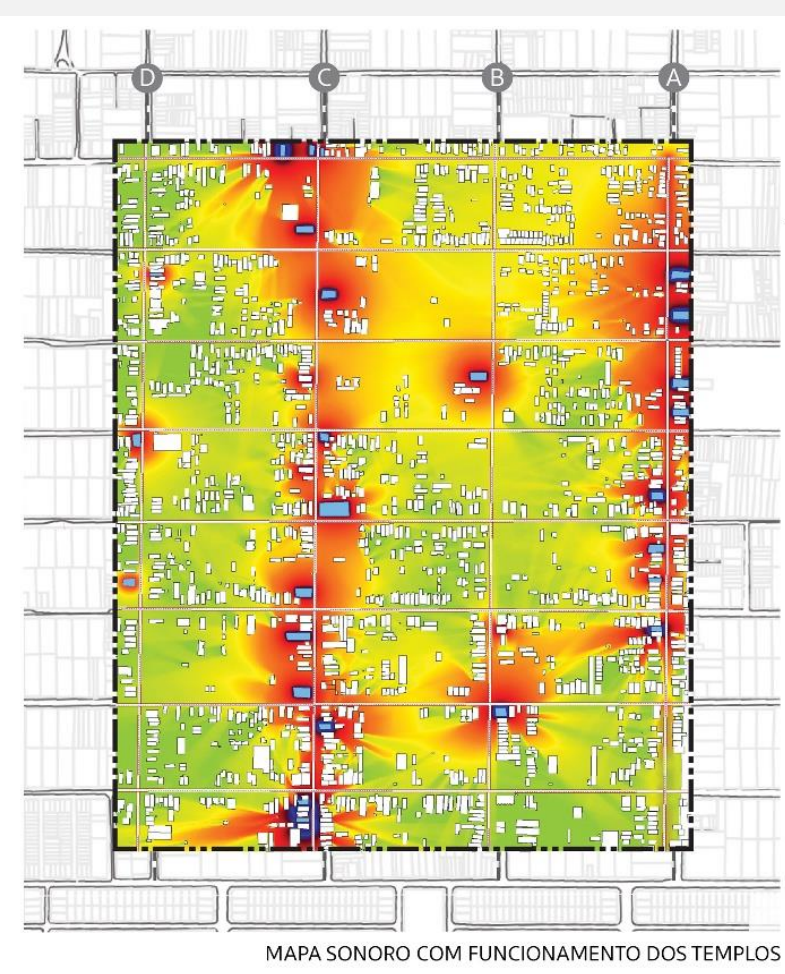

MAPA SONORO COM FUNCIONAMENTO DOS TEMPLOS
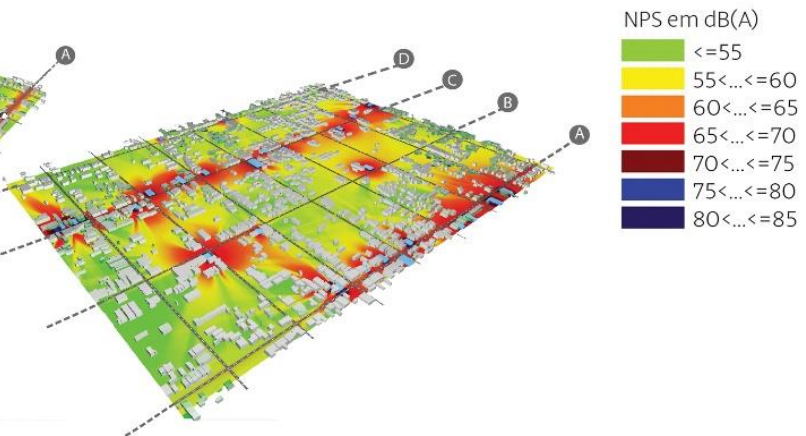

LEGENDA:

- RECEPTOR Sonoro

- TEMPLO

A AV.TANCREDO NEVES

B RUA PADRE CÍCERO

C RUA GABINO BESOURO

(D) RUASENADORARNON DE MELO

Figura 10 - Mapas acústicos simulados no software CADNA-A, sem o funcionamento dos templos (diurno) e com o funcionamento dos templos (noturno). Fonte: Autores (2017).

As medições aconteceram em uma parcela de templos localizados nas ruas principais, com funcionando dentro do intervalo de tempo das medições (18h às $22 \mathrm{~h}$ ), porém, existem outros templos localizados nas ruas transversais, o que podem impactar no ambiente sonoro.

\section{Mapeamento sonoro perceptivo}

A partir dos dados obtidos com o questionário, foram elaborados os mapas perceptivos, construídos com base na percepção sonora dos moradores locais entrevistados. Foram eles: 1. a paisagem sonora no momento de aplicação do questionário, em tempo real e a partir do uso da memória; 2. os sons escutados diariamente; 3. os sons que causam incômodo e; 4. os sons que agradam. Para os sons escutados em tempo real, foram registradas as respostas no mapa de acordo com o local de aplicação do questionário. Para as outras três perguntas, que necessitavam do uso da memória, as respostas foram posicionadas no mapa de acordo com o endereço dos moradores participantes.

0 perfil dos respondentes foi composto por $52 \%$ do sexo feminino e $48 \%$ do sexo masculino, com idade predominante de 26 a 50 anos (44\%). 82\% da amostragem foi composta por pessoas que declararam ter religião, sendo $56 \%$ de católicos e $26 \%$ evangélicos.

Em relação à paisagem sonora do local, percebida no momento da aplicação do questionário, nota-se que as principais fontes sonoras citadas pelos entrevistados são os veículos, isso devido ao fato do questionário ser aplicado nas calçadas, margeando as vias. Por exemplo, a rua A é um corredor de ônibus e 
nela é onde está a maior concentração de ícones de veículos (Figura 11). 0 segundo ponto mais respondido, foi "nenhum", o que levanta um ponto interessante sobre a percepção das pessoas quanto ao ambiente acústico, há pouco estímulo. Foram citados também, sons como: músicas provenientes de automóveis ou vizinhos e barulhos relacionados à casa dos vizinhos como conversas, TV e eletrodomésticos. Sons da natureza foram citadas em menor escala, como vento e pássaros, visto que a área possui poucas áreas verdes (Figura 11).

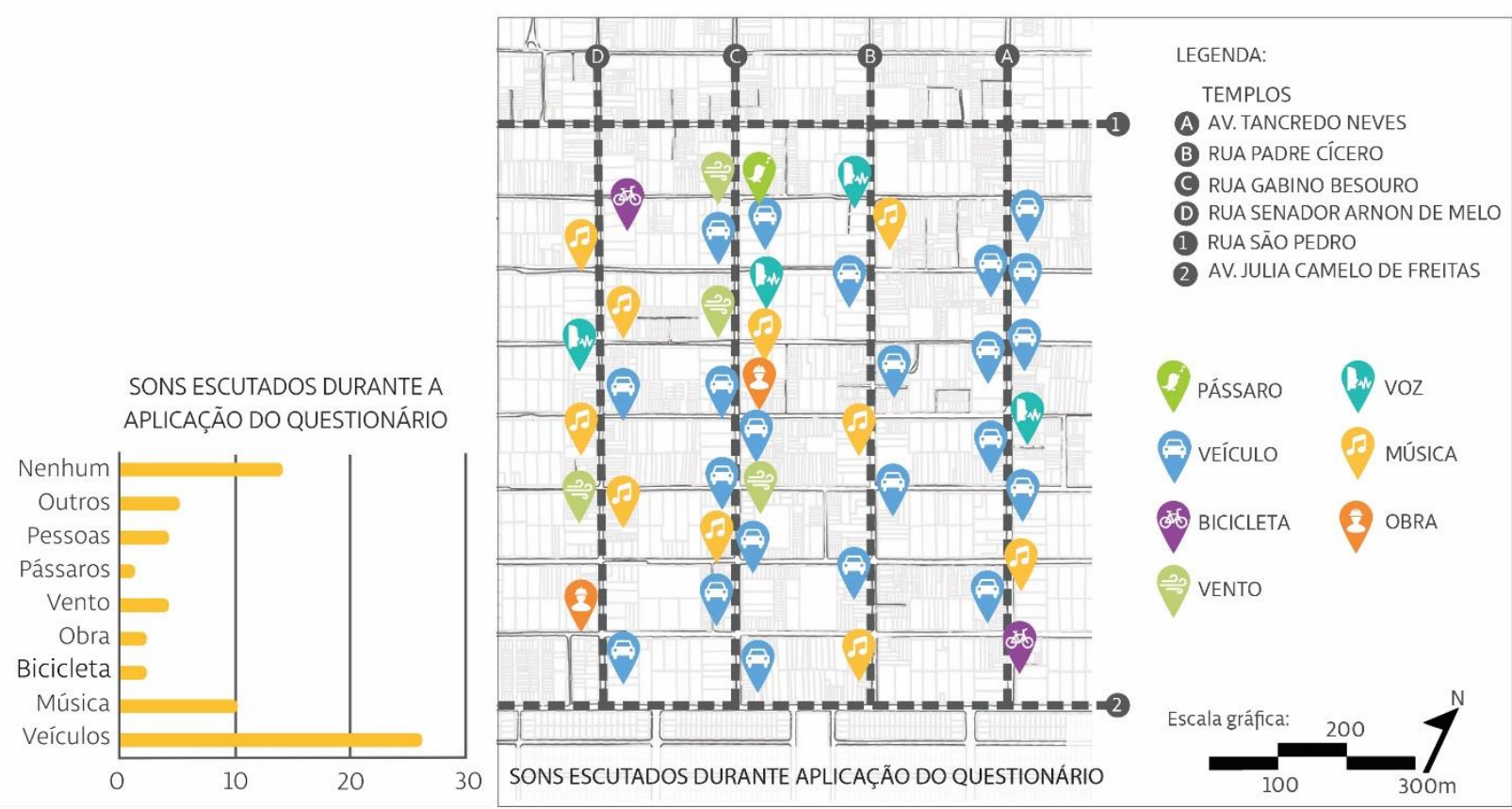

Figura 11 - Quantitativo de respostas dos sons escutados durante a aplicação do questionário. Mapa com distribuição das respostas. Fonte: Autores (2017).

Nos sons escutados diariamente, observa-se a presença de sons de veículos, de fontes sonoras pontuais como casa de vizinho, bares e igrejas. "Nenhum" também foi uma resposta recorrente nos sons escutados diariamente, o que reforça a dificuldade de perceber os sons e utilizar da memória acústica. Os sons dos templos foram mais citados na rua C onde há maior concentração dos mesmos (Figura 12).

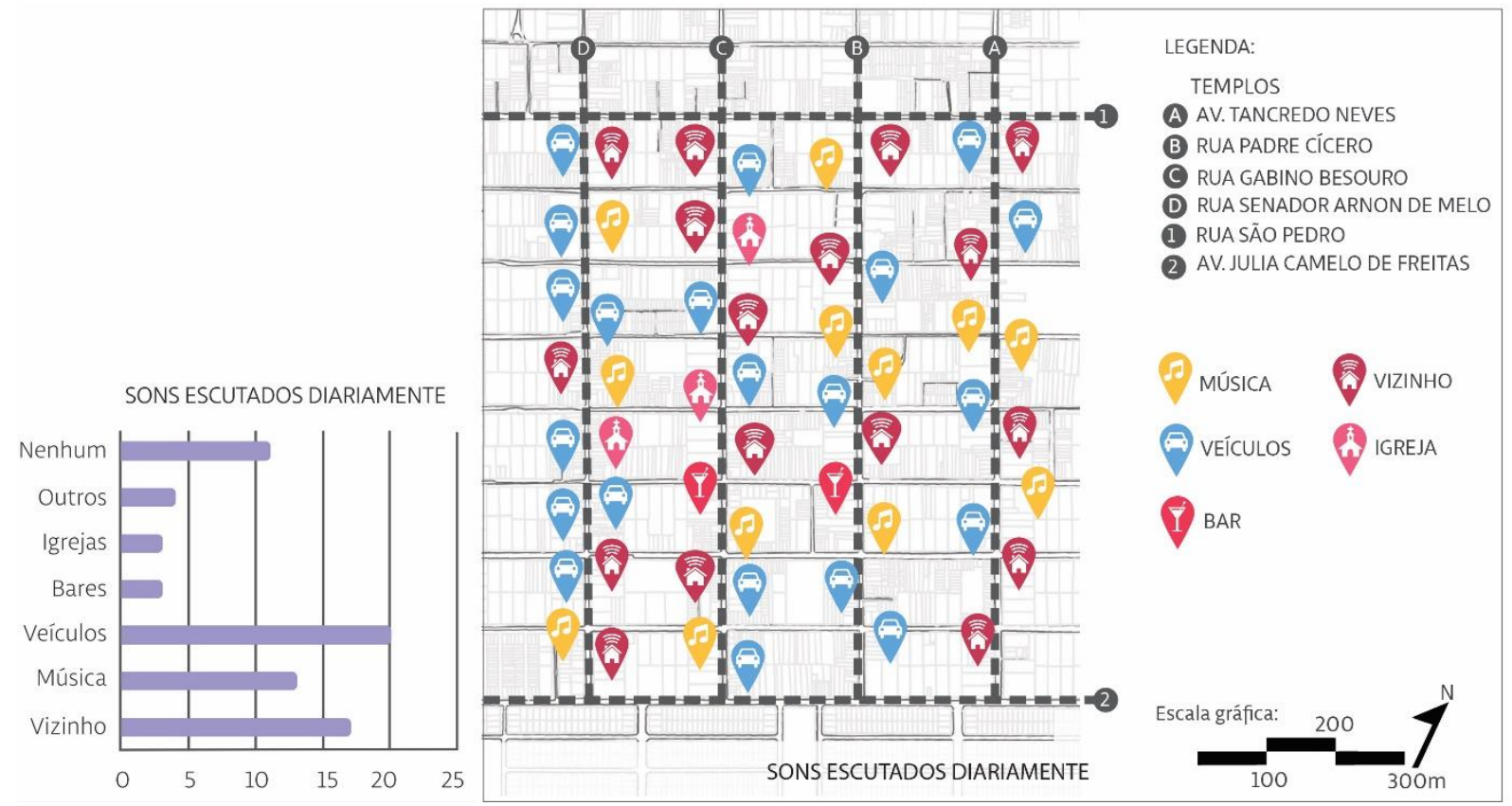

Figura 12 - Quantitativo de respostas dos sons escutados diariamente. Mapa com distribuição das respostas. Fonte: Autores (2017). 
Ao serem questionadas sobre incômodos sonoros no loteamento, $56 \%$ declararam não sentir incômodo sonoro ${ }^{10}$. Dentre os $44 \%$ dos entrevistados que responderam existir/perceber algum ruído, as principais queixas foram relacionadas a vizinhos, bares, veículos e som alto (Figura 13).

Observa-se que os templos são citados em menor proporção quando comparados às outras fontes sonoras. No cruzamento de dados do questionário é possível identificar a relação entre a religião com essa resposta, pois as pessoas que relataram incômodo com os sons dos templos não possuíam religião ou eram católicos, queixando-se dos ruídos nas igrejas protestantes. As maiores reclamações sobre os sons que incomodam foram na rua B, com destaque para bares e sons de carros.

Os sons dos veículos foram bastante citados nas perguntas sobre sons escutados diariamente e no momento da aplicação dos questionários, mas quanto ao ruído, este tipo de som foi pouco citado. Os destaques foram: equipamentos de som em carros e casas. Os ruídos domésticos e os advindos de atividades de lazer são denominados como ruídos de vizinhança, sendo significativos na percepção subjetiva do ruído urbano. Essas fontes sonoras são, também, responsáveis pela situação de desconforto da população.

EXISTE ALGUM SOM NO LOTEAMENTO QUE TE INCOMODE?

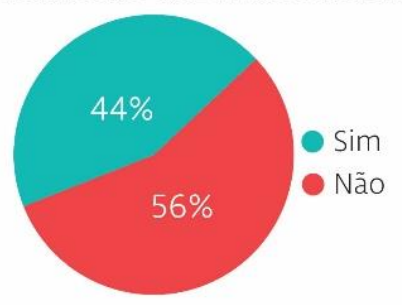

QUAIS?

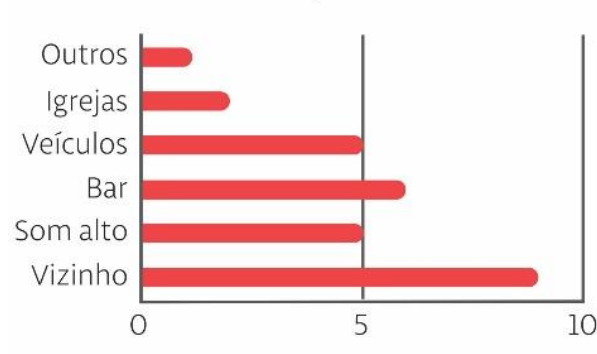

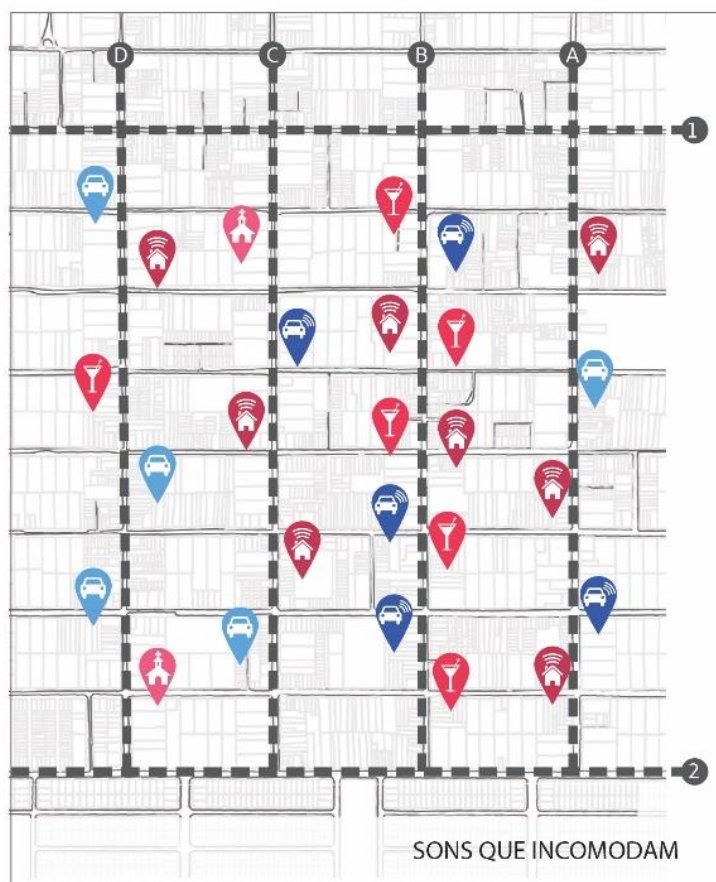

\section{LEGENDA:}

TEMPLOS

A AV. TANCREDO NEVES

B RUA PADRE CÍCERO

C RUA GABINO BESOURO

(D RUA SENADOR ARNON DE MELO

(1) RUA SĀO PEDRO

2 AV. JULIA CAMELO DE FREITAS
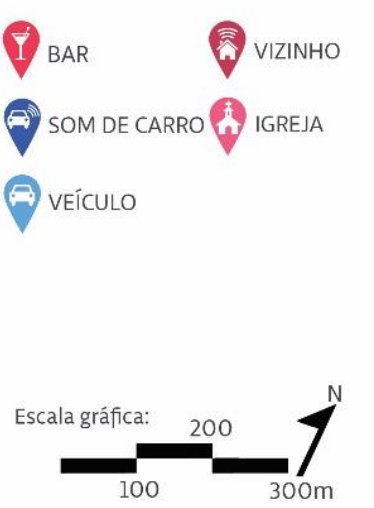

Figura 13 - Quantitativo de respostas dos sons que incomodam. Mapa com distribuição das respostas. Fonte: Autores (2017).

Em relação aos sons agradáveis, apenas 34\% das pessoas declararam que eles existiam no loteamento, e dentre estas, a maioria (45\%) apontaram o som das igrejas como o mais agradável.

A percepção dos sons positivos ainda foi menor quando comparada aos sons negativos, consequentemente o mapa sonoro apresentou um número reduzido de ícones representativos (Figura 14). Ainda há dificuldades por parte dos moradores em reconhecer os sons positivos, principalmente no contexto da poluição sonora das cidades onde os ruídos são evidenciados.

\footnotetext{
10 Percebe-se uma diminuição de ícones de respostas no mapa, quando comparado aos mapas anteriores.
} 


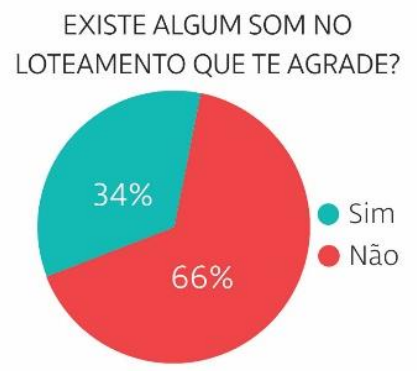

QUAIS?

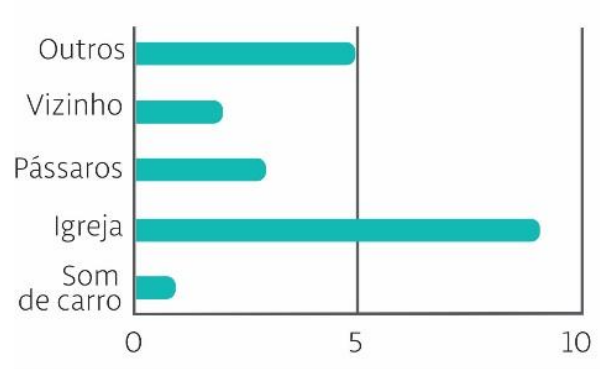

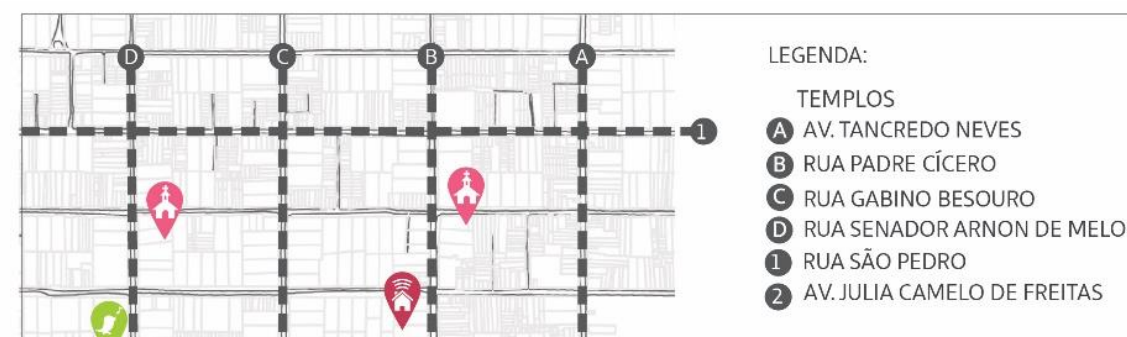

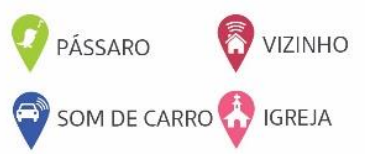

Figura 14 - Quantitativo de respostas dos sons que agradam. Mapa com distribuição das respostas. Fonte: Oliveira (2017).

Quando realizada a correlação de Pearson ${ }^{11}$ entre os dados dos sons escutados diariamente e os sons que incomodam, foi encontrado um valor baixo de correlação, $r$ 0,26. Para esta análise, foram considerados os grupos de sons: vizinhos, música, veículos, bar, igrejas e outros. A Figura 15 mostra os valores em percentil de respostas. 0 coeficiente de correlação entre sons escutados diariamente e sons que incomodam foi maior quando comparado ao coeficiente de correlação entre sons escutados diariamente e sons que agradam, que foi negativo, com $r-0,5$, e mostrou que as variáveis estão inversamente relacionadas.

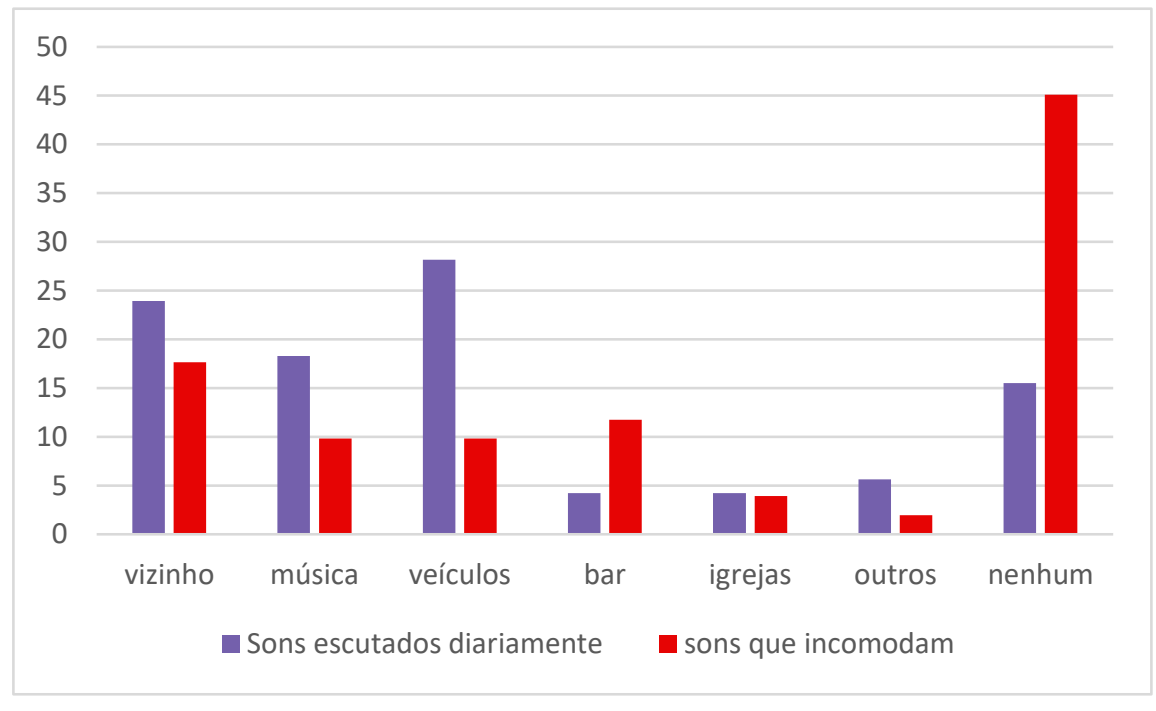

Figura 15 - Quantitativo de respostas entre sons escutados diariamente e sons que incomodam. Fonte: Autores (2021).

As edificações consideradas mais barulhentas dentro do loteamento foram os bares (20\%), seguidas pelas residências (13\%), igrejas (13\%), outros (5\%), não tem (5\%) e comércio (2\%).

Para a maioria dos questionados (56\%), os sons provenientes das igrejas são agradáveis e $20 \%$ os apontaram como desagradáveis (Figura 16). Apenas 4\% dos moradores entrevistados disseram não escutar

110 coeficiente de correlação de Pearson é uma medida do tamanho do efeito entre variáveis e está limitado ao intervalo entre 0 (sem efeito) a 1 (um efeito perfeito) (Field, 2009). 
os sons dos templos em suas residências. Esse dado correlaciona com o quantitativo de 73 edificações religiosas no loteamento Village Campestre, pois são encontrados distribuídos por toda área.

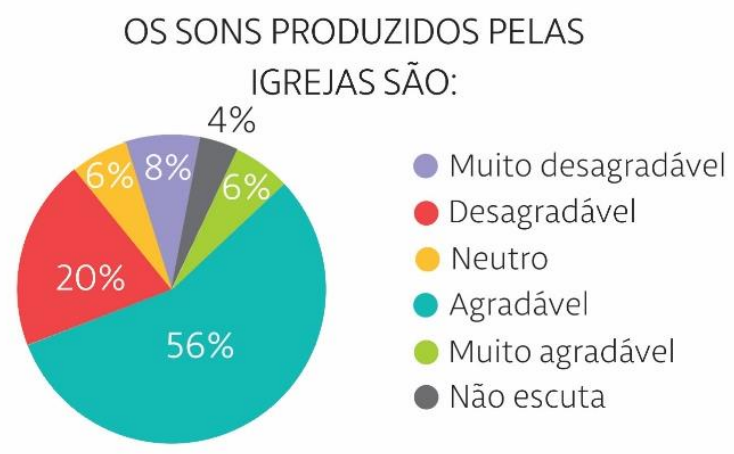

Figura 16 - Agradabilidade dos sons produzidos pelos templos. Fonte: Autores (2017)

Dentre os entrevistados que responderam considerar os templos como as edificações mais barulhentas, os católicos foram maioria (Figura 17). A maior reclamação foi sobre os sons dos templos protestantes, que possuem um ritual religioso com os NPS mais elevados.

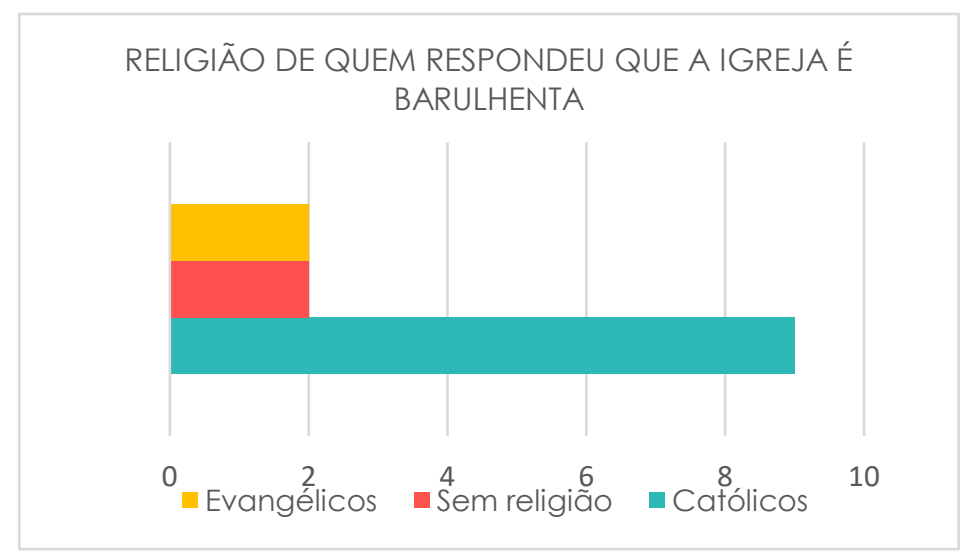

Figura 17 - Religiões que apresentaram maior incômodo com os sons das igrejas. Fonte: Autores (2017).

Os entrevistados consideraram os sons dos templos adequados (50\%), alto (24\%), muito alto (24\%) e baixo (2\%). Quando os dados sobre a agradabilidade e intensidade do som são cruzados, nota-se que nem todas as pessoas que consideram o som das igrejas agradável ou muito agradável (62\%) declararam que o volume seja adequado. Apesar de a avaliação quantitativa das medições de níveis de pressão sonora externos às igrejas ter apresentado extrapolação de valores recomendados pela NBR 10151, metade dos entrevistados expressaram considerar os sons adequados.

\section{Considerações finais}

Este artigo propôs e demonstrou uma ferramenta de mapeamento sonoro para analisar fontes pontuais (templos) na paisagem sonora. Uma estrutura de mapeamento foi proposta considerando dois tipos principais de mapas, o de fonte sonora (identificação de fontes sonoras e distribuição de NPS) e o de qualidade perceptual do ambiente sonoro (percepção das pessoas). Por meio dessas análises foi possível caracterizar a paisagem sonora do loteamento Village Campestre e investigar a inserção e impacto sonoro dos templos.

A combinação das análises de mapeamento de fonte sonora com mapeamento sonoro perceptual, ambos com foco em fontes pontuais (templos), é a contribuição mais significativa deste estudo para a comunidade científica, considerando a falta de estudos nacionais e internacionais. 
Os resultados mostraram que a proposta metodológica é eficaz em derivar informações relevantes para a caracterização da paisagem sonora e avaliação de um tipo de fonte pontual no contexto sonoro. A paisagem sonora do local de teste foi abordada sobre perspectivas diferentes (sons, ruídos e percepção sonora) para fornecer novos insights sobre o ambiente sonoro e possibilitar uma análise mais ampla. Quando estudada a percepção dos entrevistados aliada aos valores do descritor LAeq,T e seus respectivos mapas:

- Identificou-se o impacto dos sons religiosos no estudo de caso. Com a análise dos dados das medições acústicas, percebeu-se o impacto dos templos com altos níveis de LAeq,T, quando comparados à NBR 10151, o valor ultrapassa em média $20 \mathrm{~dB}(\mathrm{~A})$ do recomendado pela normativa que é de $50 \mathrm{~dB}(\mathrm{~A})$ no turno noturno. Porém, quando analisada as respostas do questionário e os mapas perceptivos, pôde-se considerar um efeito positivo dos sons religiosos, pois os entrevistados consideravam adequados e agradáveis;

- Apesar de o estudo de caso apresentar maior quantitativo de entrevistados que não percebem os sons positivos, a percepção dos sons da fé como agradáveis é quatro vezes maior do que como desagradáveis;

- Na percepção dos participantes, notou-se maior aceitação dos sons das igrejas como positivos quando eles pertenciam a religião do indivíduo. Apesar de serem considerados altos, os sons dos templos foram, em sua maioria, tidos como agradáveis, neste caso, não se vincula a agradabilidade com a intensidade do som.

Apesar de apresentar informações relevantes sobre a percepção dos entrevistados, esta investigação mostrou limitações devido ao tamanho da amostragem de entrevistados, no quesito de representação da comunidade. Portanto, em trabalhos futuros, pode-se adotar uma amostragem mais representativa, além de inserir nas análises parâmetros psicoacústicos (como loudness, sharpness) para a produção de mapas sonoros e medições acústica in situ em bandas de frequência terço de oitava.

O estudo realizado atestou que o mapa de paisagem sonora é uma ferramenta estratégica de diagnóstico, uma vez que é um facilitador na comunicação de análises por fornecer visualmente e geograficamente a propagação dos sons. 0 mapeamento proposto pode ser utilizado como ferramenta para a análise e gerenciamento de fontes pontuais no espaço urbano. Sendo assim, esta pesquisa corrobora com os estudos de ambientes sonoros individualizados, o que ajuda a reconhecer e preservar a identidade de paisagens sonoras.

\section{Declaração de disponibilidade de dados}

O conjunto de dados que dá suporte aos resultados deste artigo está disponível no SciELO DATA e pode ser acessado em https://doi.org/10.48331/scielodata.KV9SVU.

\section{Referências}

Associação Brasileira de Normas Técnicas - ABNT. (2019). NBR 10.151: Acústica - Avaliação do ruído em áreas habitadas, visando o conforto da comunidade - Procedimento. 4. Rio de Janeiro: ABNT.

Aletta, F., Kang, J., \& Axelsson, O. (2016). Soundscape descriptors and a conceptual framework for developing predictive soundscape models. Landscape and Urban Planning, 149(x), 65-74. http://dx.doi.org/10.1016/j.landurbplan.2016.02.001.

Aletta, F., \& Kang, J. (2015). Soundscape approach integrating noise mapping techniques: A case study in Brighton, UK. Noise Mapping, 2, 1-12. https://doi.org/10.1515/noise-2015-0001.

Brambilla, G., \& Pedrielli, F. (2020). Smartphone-based participatory soundscape mapping for a more sustainable acoustic environment. Sustainability, 12(19), 1-20. https://doi.org/10.3390/su12197899.

Brandão, A., \& Jorge. A. (2019). The recent fragmentation of the religious landscape in Brazil: In search of explanations. Revista de Estudios Sociales, 69, 79-90. https://doi.org/10.7440/res69.2019.07. 


\section{Mapeamento da paisagem sonora}

Brito, L., Carvalho, J., \& Toledo, V. (2018). A eficiência de algoritmos matemáticos para avaliação do ruído urbano. Urbe. Revista Brasileira de Gestão Urbana, 10, 22-35. https://doi.org/10.1590/2175-3369.010.001.ao03.

De Witte, M. (2008). Accra's sounds and sacred spaces. International journal of urban and regional research, 32, 607-709. https://doi.org/10.1111/j.1468-2427.2008.00805.x.

Field, A. (2009). Descobrindo a estatística usando o SPSS (2a ed., vol. 1). Porto Alegre: Artmed.

Ge, J., Lu, J., Morotomi, K., \& Hokao, K. (2009). Developing Soundscapegraphy for the Notation of Urban Soundscape: Its Concept, Method, Analysis and Application. Acta Acustica, 95(1), 65-75. https://doi.org/10.3813/AAA.918128.

Hedblom, M., Knez, I., Sang, Â., \& Gunnarsson, B. (2017). Evaluation of natural sounds in urban greenery: Potential impact for urban nature preservation. Royal Society Open Science, 4(2). https://doi.org/10.1098/rsos.170037.

Henriques, L. (2017). A paisagem sonora de Angra no século XVII: Uma perspectiva a partir da actividade das suas instituições religiosas. In Anais do Congresso Internacional, Centro Cultural Vila Flor (Guimarães). (p. 175-196). Évora: Câmara Municipal de Guimarães.

Hong, J. Y., \& Jeon, J. Y. (2017). Relationship between spatiotemporal variability of soundscape and urban morphology in a multifunctional urban area: A case study in Seoul, Korea. Building and Environment, 126, 382-395.

https://doi.org/10.1016/j.buildenv.2017.10.021.

Instituto Brasileiro de Geografia e estatística - IBGE. (2010). SIDRA - Sistema IBGE de Recuperação Automática. Recuperado em 16 de fevereiro de 2017, de https://sidra.ibge.gov.br/home/ipca/brasil.

International Organization for Standardization - ISO. (2018). ISO 12913: Acoustics - Soundscape. Part 2: Methods and measurements. Geneva: ISO.

Jenning, P., \& Cain, R. (2013). A framework for improving urban soundscapes. Applied Acoustic, 74, 293-299.

https://doi.org/10.1016/j.apacoust.2011.12.003.

Kang, J. (2007). Urban Sound Environment. (1a ed.). Londres: Taylor \& Francis.

Kang, J., Aletta, F., Margaritis, E., \& Yang, M. (2018). A model for implementing soundscape maps in smart cities. Noise Mapping, 5(1), 46-59. https://doi.org/10.1515/noise-2018-0004.

Kogan, P., Arenas, J., Bermejo, F., Hinalaf, M., \& Turra, B. (2018). A Green Soundscape Index (GSI): The potential of assessing the perceived balance between natural sound and traffic noise. Science of the Total Environment, 642, 463-472.

https://doi.org/10.1016/j.scitotenv.2018.06.023.

Klæboe, R., Engelien, E., \& Steinnes, M. (2006). Context sensitive noise impact mapping. Applied Acoustics, 67(7), 620-642. https://doi.org/10.1016/j.apacoust.2005.12.002.

Kovačič, M. (2017). Official Regulations and Perceptual Aspects of Bell Ringing. Muzikologija, 22(22), 59-73. https://doi.org/10.2298/MUZ1722059K.

Kovačič, M. (2018). What should a town sound like? Religious and street sounds in ljubljana between legislation and human experience. Etnolog., 28, 123-140.

Labelle, B. (2010). Acoustic Territories: Sound culture and everyday life (1a ed., vol. 1). Berlin: Continuum.

Liu, J., Kang, J., Luo, T., Behm, H., \& Coppack, T. (2013). Spatiotemporal variability of soundscapes in a multiple functional urban area. Landscape and Urban Plannig, 115, 1-9. https://doi.org/10.1016/j.landurbplan.2013.03.008.

Liu, J., Kang, J., Behm, H., \& Luo, T. (2014). Landscape spatial pattern indices and soundscape perception in a multifunctional urban area, Germany. Journal of Environmental Engineering and Landscape Management, 22, $208-2018$. https://doi.org/10.3846/16486897.2014.911181.

Liu, Q., Liu, Z., Jiang, J., \& Qi, J. (2020). A new soundscape analysis tool: Soundscape Analysis and Mapping System (SAMS). Applied Acoustics, 169. https://doi.org/10.1016/j.apacoust.2020.107454.

Maceió (2007, fevereiro). Lei n. 5.593, de 08 de fevereiro de 2007. Institui o Código de Urbanismo e edificações do município de Maceió. Maceió: Portal da Prefeitura de Maceió.

Mardones, M. (2009). Mapeamento dos níveis de ruído em Copacabana, Rio de Janeiro, através de simulação computacional (Dissertação de mestrado). Instituto Alberto Luiz Coimbra de pós-graduação e pesquisa em Engenharia, Universidade Federal do Rio de Janeiro, Rio de Janeiro. 
Margaritis, E., \& Kang, J. (2017). Soundscape mapping in environmental noise management and urban planning: Case studies in two UK cities. Noise Mapping, 4(1), 87-103. https://doi.org/10.1515/noise-2017-0007.

Mendonça, A, Suriano, M., Souza, L. \& Viviani, E. (2013). Classes de quadras urbanas determinadas pelos níveis de ruídos. Urbe. Revista Brasileira de Gestão Urbana, 5(2), 63-77. https://doi.org/10.7213/urbe.05.002.SE05.

Oliveira, P. (2017). Habitar entre sons e ruídos: impactos sonoros provocados por templos na paisagem sonora do loteamento Village Campestre, Maceió-AL (Dissertação de mestrado). Universidade Federal de Alagoas, Maceió.

Prefeitura Municipal de Maceió - Base Cartográfica de Maceió (2000). Base de Dados [CD-ROM]. Maceió.

Robert, M., \& Hayden, T. D. W. (2013). Intersecting Religioscapes: A Comparative Approach to Trajectories of Change, Scale, and Competitive Sharing of Religious Spaces. Journal of the American Academy of Religion, 81, 399-426. https://doi.org/10.1093/jaarel/lft009.

Romero, V., Maffei, L., Brambilla, G., \& Ciaburro, G. (2016). Modelling the soundscape quality of urban waterfronts by artificial neural networks. Applied Acoustics, 111, 121-128. https://doi.org/10.1016/j.apacoust.2016.04.019.

Schafer, M. (1977). A Afinação do mundo - uma exploração pioneira pela história passada e pelo atual estado do mais negligenciado aspecto do nosso ambiente: a paisagem sonora (1a ed., vol.1). São Paulo: Editora UNESP.

Szeremeta, B., \& Zannin, P. (2009). Analysis and evaluation of soundscapes in public parks through interviews and measurement of noise. Science of The Total Environment, 407, 6143-6149.

https://doi.org/10.1016/j.scitotenv.2009.08.039.

Szeremeta, B., \& Zannin, P. (2015). A percepção dos praticantes de atividade física sobre a qualidade ambiental sonora dos parques públicos de Curitiba-Paraná. Raega, o espaço geográfico em análise, 33, 07-43. https://doi.org/ 10.5380/raega.v33i0.

Truax, B. (2001). Acoustic Communications (1a ed. Vol.1). Westport: Greenwood.

Valques, I. (2016). Avaliação da qualidade ambiental acústica urbana: parametrização e quantificação das variáveis que influenciam a percepção da paisagem sonora, através da análise multivariada, no campus sede da Universidade Estadual de Maringá (Tese de doutorado). Instituto de Arquitetura e Urbanismo, Universidade de São Paulo, São Carlos.

Vogiatzis, K., \& Remy, N. (2017). Soundscape design guidelines through noise mapping methodologies: An application to medium urban agglomerations. Noise Mapping, 4(1), 1-19. https://doi.org/10.1515/noise-2017-0001.

Xiao, J., \& Aletta, F. (2016). A soundscape approach to exploring design strategies for acoustic comfort in modern public libraries: A case study of the Library of Birmingham. Noise mapping, 3, 264-273. https://doi.org/10.1515/noise-20160018.

Editor responsável: Paulo Nascimento Neto

Recebido: 19 mar. 2021

Aprovado: 22 jul. 2021 